\title{
Whom (Or What) Does the Organization's Lawyer Represent?: An Anatomy of Intraclient Conflict
}

\author{
William H. Simon $\dagger$
}

\section{TABLE OF CONTENTS}

Introduction.

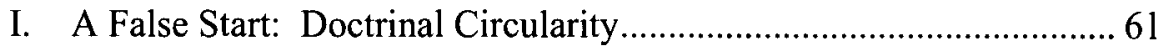

II. Organizational Representation as Joint Representation .......................65 65

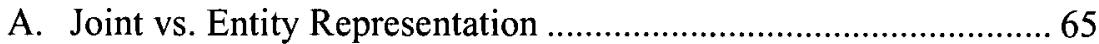

B. Piercing the Veil for Professional Responsibility Purposes.......... 67

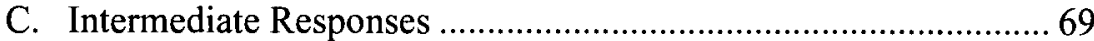

I. "Reasonable Expectations" and Additional Representation... 70

2. Aiding and Abetting Liability ............................................. 72

3. Retroactively Imposing the Corporate Veil........................... 73

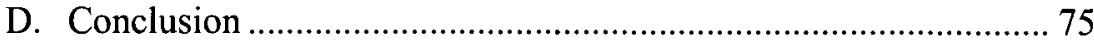

III. Entity Representation I: The Organization as Control Group ............ 75

IV. Entity Representation II: The Organization as Authority Structure ... 80

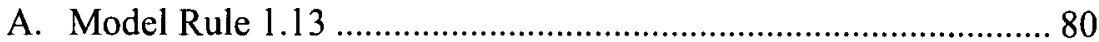

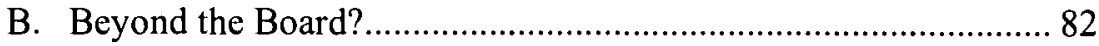

C. Limits of the Authority Structure Perspective .............................. 83

V. Entity Representation III: the Organization as Framework of

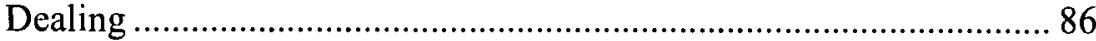

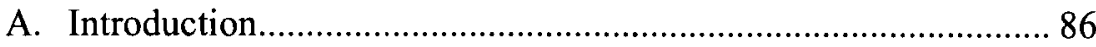

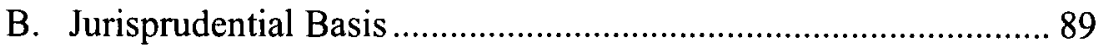

I. The Framework of Dealing .................................................. 89

2. The Importance of Distributive Norms ................................ 9 I

3. The Irrelevance of the Direct-Derivative Distinction............. 96

C. Doctrinal Applications ............................................................ 98

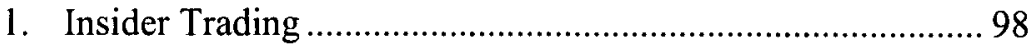

Copyright $\bigcirc 2003$ California Law Review, Inc. California Law Review, Inc. (CLR) is a California nonprofit corporation. CLR and the authors are solcly responsible for the content of their publications.

$\dagger \quad$ William and Gertrude Saunders Professor of Law, Stanford University. Thanks for help and encouragement to Joe Bankman, Steve Bundy, Sam Isacharoff, Mike Klausner, John Leubsdorf, Larry Mitchell, Richard Painter, and participants at workshops at Columbia Law School, Florida State University Collegc of Law, and University of Miami Sehool of Law. 
2. Derivative-Suit Defense 99

3. Duties to Nonshareholder Constituents.............................. 101

VI. The Entity Approach Summarized and Compared............................ 103

A. An Integrated Entity Approach ................................................... 103

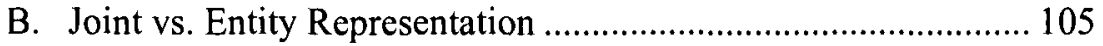

C. The Limited Potential of Client Prescription ............................. 109

VII. Noncorporate Organizations.................................................... 110
A. Partnerships 110
B. Personal Trusts
C. Charitable Organizations II 2
D. Informal Associations 


\title{
Whom (Or What) Does the Organization's Lawyer Represent?: An Anatomy of Intraclient Conflict
}

\author{
William H. Simon
}

Professional responsibility issues involving organizational clients are distinctively difficult because organizations consist of constituents with conflicting interests. Legal doctrine has only recently begun to address the effect of internal conflict on a lawyer's responsibilities to an organizational client. Under current doctrine, the lawyer's responsibilities differ strongly depending on whether the representation is characterized as "joint" representation of the organization's constituents or "entity" representation. This Article argues that the choice between the two characterizations often has been arbitrary and that the underlying differences between them have been misunderstood. With respect to entity representation, it criticizes a prominent tendency in the cases to conflate the interests of the organization with the goals of its controlling management. It also criticizes the approaches of the Model Rules of Professional Conduet and the Restatement of the Law Governing Lawyers, which identify the entity with its authority structure. These approaches suffer from the influence of anachronistic corporate law doctrine that defines the interests of an organization largely in terms of maximizing aggregate benefits and ignores norms of fair distribution among constituents. An adequate understanding of organizational representation requires a view of the corporation as a "Framework of Dealing" that includes both control or authority norms and distributive norms. The analysis focuses on corporations, but a concluding Part VII shows that it also applies to other organizational forms.

\section{INTRODUCTION}

A large fraction of the bar spends its time representing organizations. The law tends to characterize these organizations as unitary "entities" or "legal persons" and to suggest that lawyers' duties to such clients are analogous to their duties to individual clients. In fact, however, these organizations consist of multiple individuals with potentially differing interests, and hence they are prone to internal conflicts that do not arise in individual representation. 
For most of the bar's history, there was little discussion of such conflicts, but a substantial body of authority has emerged in recent years applying both substantive corporate law doctrine and professional responsibility norms to lawyers in situations of what might be called "intraclient" conflict. For the most part, this authority responds to three broad categories of claims:

(1) Breach of Duty: The lawyer is charged with breach of duty, as a matter of either professional discipline or tort liability, for assisting or acquiescing in conduct by some organizational constituents that allegedly wrongfully injures others.

(2) Disqualification: Either the organization or a constituent argues that the lawyer is subject to disqualification on conflict-of-interest grounds.

(3) Privileged Communications: An organizational eonstituent alleging management wrongdoing seeks access to privileged communications between management and counsel.

Doctrinal responses to these claims have been incoherent and implausible. This Article offers some suggestions to clarify thinking about organizational representation and some specific solutions for current controversies. It criticizes a common tendency to invoke the idea of entity representation in an unreflective and question-begging way. Often the interests of the organization are eonflated with those of management. A more sophisticatcd approach, exemplified by the ABA Model Rules of Professional Conduct ("Model Rules") 1 and the Restatement of the Law Governing Lawyers ("Restatement"), ${ }^{2}$ treats the organization as a structure of authority. Even this approach is inadequate in many situations, however. This Article argues that a satisfactory approach would understand the corporation as a "Framework of Dealing," a set of procedural and substantive terms grounded in the understandings of the organization's constituents and supplemented by publicly provided default and mandatory terms. These terms generate convergent expectations that make it possible to treat the organization as a unitary elient.

The Framework of Dealing perspective refleets the most plausible jurisprudential understanding of the nature of organizations. However, it entails revision of some anachronistic corporate doctrine, such as the distinction between "direct" and "derivative" constituent claims, that has stunted professional responsibility standards in this area. This doctrine implies a conception of organizational identity in which the organization is indifferent to the integrity of its distributive commitments. Under the influence of this conception, courts often assume that a lawyer's duty of loyalty

1. Model Rules of Prof'l Conduct (2001) [hereinafter Model Rules].

2. Restatement (ThiRd) of the LaW Governing Lawyers (2001) [hereinafter Restatement of the LaW Governing LaWyers]. 
to an organizational client does not entail any obligation to protect its distributive arrangements. Nevertheless, a more plausible view that recognizes the centrality of distributive norms to client identity can be seen in some areas of doctrine.

I begin with a hypothetical to illustrate the issues. It uses a close corporation because the problems with present doctrine are most visible in this context, but I will later suggest that the analysis developed in response to this situation also applies to larger organizations. I proceed to contrast joint representation of individuals with "entity" representation and to consider suggestions that joint-representation norms should be applied to some clients that are, nominally, organizations. I then consider three interpretations of "entity" representation. The first identifies the corporation with its control group, the second with its authority structure, and the third with a comprehensive framework of dealing. I argue that the third perspective is most promising. The analysis is developed for the most part with reference to business corporations. Toward the end, I consider authority on a variety of other types of organizations--partnerships, trusts, charitable organizations, and informal associations-and conclude that the Framework of Dealing perspective fits these contexts as well.

\section{A False Start: Doctrinal Circularity}

\section{THE FOUNDER FREEZE-OUT}

Founder, the principal entrepreneur and technical spirit of Hi-Tech, Inc., is an engineer who developed a new gizmo-a critical component of various electronics products. Shortly after Founder set up the corporation, Investor, a venture-capital partnership, became a major shareholder. Investor owns preferred stock, and under relevant terms of the Articles of Incorporation, it is entitled to take control of the board of directors ("board") if specified financial milestones are not met, including one regarding revenues.

Product development and marketing have exceeded expectations, but the enterprise encountered unanticipated production problems. Soon thereafter, Investor asserted that the revenue milestone had not been met, and with Founder's acquiescence, assumed control. The Investor-controlled board then informed Founder that his services as an employee were no longer needed by the firm. The board exercised the firm's option to repurchase Founder's stock on his departure from the firm. Half of these shares were unvested and hence were subject to repurchase at the price Founder paid for them, which was a small fraction of their market value. At the next shareholder meeting, Founder was replaced as a director. 
One of the Investor directors has told Hi-Tech's corporate counsel that, according to the firm's accountant, the claim that the milestone has not been met-the basis for Investor's assumption of control of the boardrests on a debatable accounting judgment (about, say, when orders should be booked). "It could have gone either way," the accountant said. Founder is unaware of the accountant's view, and neither the accountant nor the directors have any intention of telling him of it. What should corporate counsel do?

The position most strongly supported by judicial authority is probably that counsel has no duty to inform Founder and may have an affirmative duty not to do so. ${ }^{3}$ There is also ample support for the proposition that counsel may represent the corporation in litigation against Founder over his separation. ${ }^{4}$ And there is authority that the board will be able to invoke attorney-client privilege to preclude Founder from deposing counsel in subsequent litigation. ${ }^{5}$ As we will see, there is also differing authority with respect to each of these issues, and indeed the last position on attorneyclient privilege appears to be a minority one. But few cases or commentators have confronted the flawed logic that pervades this body of doctrine.

The holdings against the shareholder usually are supported with the claim that corporate counsel represents the corporation, not its constituents. This precept is typically invoked without elaboration as if it were sufficient on its face to dispose of the shareholders' claim. In fact, this precept merely raises the question of what the corporation's interests are in the circumstances of the case. The implicit answer the cases give is often highly implausible.

To take an extreme, but far from unique, case, consider Skarbrevik $v$. Cohen, England \& Whitfield, ${ }^{6}$ in which the plaintiff was one of the four shareholders in an insurance brokerage corporation. He had a falling-out with his colleagues, and they agreed to repurchase his shares. After his departure, they reneged on the repurchase agreement and instead "deliberately embarked on a scheme to greatly diminish [his] interest in the corporation by diluting his stock in violation of their fiduciary dut[ies]." ${ }^{\prime 7}$ The scheme included the filing of articles of amendment eliminating the plaintiff's preemptive rights to new shares with a declaration falsely reciting that the amendment had been duly approved at a shareholder meeting. Although the court's factual recitation suggested that the lawyer may have engaged in affirmatively fraudulent acts, the plaintiff apparently argued only that the lawyer had a duty to make timely disclosures to him of the

\footnotetext{
3. See infra notes $7 \& 10$.

4. See infra note 11.

5. See infra note 14.

6. 282 Cal. Rptr. 627 (Cal. Ct. App. 1991).

7. Id. at 637 .
} 
officers' conduct. This the court of appeal denied, opining that the lawyer's duty was to the corporation and not to Skarbrevik, whom it characterized as someone "dealing with the corporation at arm's length" with interests "adverse" to those of the corporation. ${ }^{8}$ In this and similar cases, courts, after invoking the principle that counsel's duty is to the corporation, never proceed to consider what that duty requires, and in particular, how it could be consistent with that duty to facilitate the expropriation of interests that the corporate structure allocates to the plaintiff. ${ }^{9}$

The same tendency can be found in discussions of disqualification of corporate counsel in shareholder litigation. Most lawyers think it uncontroversial that corporate counsel can represent the corporation in a dispute with a constituent such as Founder, assuming that she has never represented him individually. If the only client has been the corporation, then Founder is neither a present nor a former client, and there is no conflict that might disqualify. ${ }^{10}$

This analysis involves two assumptions. First, it assumes that representing the corporation is fundamentally different than representing

8. Id. at 637-38. This was a direct action, but the case gives no indication that the court would have looked more favorably on the claim had the action been derivative. The court's characterization of the plaintiff's interest as "adverse" to the corporation would seem to preclude derivative claims. In any event, the distinction between direct and derivative is pointless in a case where the plaintiff sues for conduct in which all the other shareholders participated. See discussion infra at Part V.B.3.

9. A case with facts, analysis, and a conclusion remarkably similar to Skarbrevik is Felty v. Hartweg, 523 N.E.2d 555 (IIl. App. Ct. 1988).

The best known case of this sort is Fassihi v. Sommers, Schwartz, Silver, Schwartz \& Tyler, 309 N.W.2d 645 (Mich. Ct. App. 1981). The case sometimes is treated as more nuanced than Skarbrevik and Felty, but the thrust is similar. Fassihi involved a corporation owned by two doctors, both of whom were on the board. Corporate counsel helped the corporation's chief executive, Dr. Lopez, oust the plaintiff, Fassihi, as a corporate employce. Unknown to Fassihi, corporate counsel had simultaneously represented Lopez in negotiating a contract between Lopez and a hospital making employment by the corporation a condition of patient-admitting privileges in the hospital. As a consequence of this private agreement, Fassihi's expulsion from the corporation led to his loss of hospital privileges. The issues considered in the opinion were whether corporate counsel had a duty to inform Fassihi of (1) his separate individual representation of Lopez, or (2) Lopez's agreement with the hospital.

The court held that the lawyer should have informed Fassihi of the separate individual reprcsentation but not of the contract. It suggested that lawyers have a limited duty to nonclicnts who repose "trust and confidence" in them and that this duty extends to the disclosure of conflicting representations. $I d$. at 648 . The holding could be interpreted to recognize limited but ambiguous fiduciary duties of corporate counsel to constituents. There is, however, a cleaner explanation for it than the one the court gives. Model Rule 4.3 creates a duty to unrepresented nonclients, even complete strangers, "[w]hen the lawyer knows or reasonably should know that the unrepresented person misunderstands the lawyer's role in the matter... [to] make reasonable efforts to correct the misunderstanding." MODEL RULES, supra note 1, at R. 4.3.

The rest of the opinion has the same cavalier and conclusory tone as that of Skarbrevik. The court rules that counsel rightly failed to disclose the hospital contract because of his duty of confidentiality to Lopez as an individual client without even acknowledging the issue of whether his duty to his corporate client required disclosure to Fassihi as a shareholder and board member. Fassihi, 309 N.W.2d at 648 50 .

10. See Seifert v. Dumatic Indus., 197 A.2d 454 (Pa. 1964) (holding that counsel for two-person corporation not disqualified from representing corporation against one of the shareholders). 
Founder when Founder is its only shareholder (prior to Investor's investment). Lawyers representing start-up companies looking for venture financing routinely ask the founders to sign letters acknowledging that counsel represents the corporation and not the founders individually and suggesting that the founders consider seeking separate individual representation. In fact, the founders never seek separate representation, and were they to do so, no one has any idea what the additional lawyer would do. At this stage, it seems impossible to draw any distinction between individual and corporate interests. Lawyers' insistence on the distinction seems to serve little purpose other than to preserve their ability to align themselves against the founders should a dispute arise after the outside investment.

The second assumption is that at the time of the dispute, incumbent management represents the interests of the corporation. This is a normal presumption, but the purpose of a claim such as the one Founder might make is to challenge it. Almost any shareholder suit challenges management's authority, and in a derivative suit, the plaintiff constituent purports explicitly to speak for the corporation. But the conventional treatment simply conflates the corporation's interests with the views of incumbent management.

Many believe that while corporate counsel may be able to represent the corporation, it should not jointly represent the corporation and the managers if the suit accuses the latter of individual wrongdoing. ${ }^{11}$ Under this view, Investor would have to retain separate counsel for itself if Founder sued it for its conduct on the board. But some authority rejects even this qualification and holds that not only can counsel represent the corporation, but she can also jointly represent the officers personally, at least if the current board consents on behalf of the corporation to the joint representation. This is the conclusion of an opinion of the California State Bar ethics committee in a case involving, like our hypothetical, litigation bctween the only two stakeholders of a corporation. The committee concluded that the shareholder-CEO (the counterpart of Investor in our scenario) could consent to joint representation. "To conclude otherwise," it says, "would permit ... the Corporation's adversary in the lawsuit to dictate how the Corporation would be represented in that proceeding." 12 Again, we get no explanation of why the plaintiff should be regarded as the corporation's "adversary."

11. See infra notes 115-19 and accompanying text.

12. State Bar of California Standing Comm. on Prof'l Responsibility and Conduct, Formal Op. 1999-153 (1999), available at http://www.calbar.org/2pub/3eth/ca99-153.htm. (In the opinion, the sharcholder in control of the corporation, to whom the opinion ascribes the right to consent to joint representation, is identified as "A.") For a contrasting view, see RESTATEMENT OF THE LAW GOVERNING LAWYERS, supra notc $2, \S 131 \mathrm{cmt}$. g (joint representation in derivative suits requires consent of "disinterested" directors). 
Courts that allow the corporation to routinely invoke attorney-client privilege against a derivative plaintiff follow the same logic. For example, the California Supreme Court explained that it lacked the authority to ereate an "exception" to an evidentiary privilege enacted by the legislature. ${ }^{13}$ Even without an exception, however, the question of who speaks for the corporation in deciding whether to invoke the privilege remained, but the court felt no need to explain its decision against the plaintiff on this matter.

In all three contexts- - breach of duty, disqualification, and confidentiality-courts treat the principle of corporate representation as conclusive against the constituent's claim by tacitly conflating the interests of the corporation with those of incumbent management. Once articulated, this view becomes considerably harder to defend, but it does have a legitimate role to play in specifying the meaning of corporate representation. It is, however, only one of at least three important interpretations of entity representation, and it is less useful for dealing with cases such as the Founder Freeze-Out than the other two. Before we consider the alternative conceptions of entity representation, however, we must consider an approach to issues of organizational representation that dispenses with the entity concept entirely.

\section{ORganizational REPRESENTATION AS JoINT REPRESENTATION}

\section{A. Joint vs. Entity Representation}

Suppose in the Founder Freeze-Out case, Founder and Investor had come to the lawyer as individuals and asked the lawyer to assist them in conducting their activities without any organization. The lawyer's activities would thus have been joint representation of Founder and Investor. If this had been the case, then counsel's obligations to Founder once the dispute with Investor arose would have been as follows:

Conflicts: Prior to undertaking to represent them jointly, she should have (1) warned Founder of the dangers of conflict with Investor, to the extent they were foreseeable; and (2) withdrawn from at least one, and probably, both representations when conflict beeame manifest. ${ }^{14}$

13. Dickerson v. Superior Court, 185 Cal. Rptr. 97, 100 (Cal. Ct. App. 1982); see also Hoiles v. Superior Court, 204 Cal. Rptr. 111 (Cal. Ct. App. 1984). By contrast, federal authority holds that the corporation is sometimes precluded from asserting attorney-client privilege against a derivative plaintiff. Garner v. Wolfinbarger, 430 F.2d 1093 (5th Cir. 1970), cert. denied, 401 U.S. 974 (1971).

14. Model Rule 1.9, which prohibits representing someone against a former client in a matter "substantially related" to the former representation, implies that when joint representation breaks down, the lawyer must cease representing both clients (unless both will consent to continued representation). Model. Rules, supra note 1, at R. 1.9; see also Brennan's, lnc. v. Brennan's Restaurants, lnc., 590 F.2d 168 (5th Cir. 1979). Some cases, however, take a less-strict approach, emphasizing that continued representation of one client does not threaten any confidentiality interest, since joint clients waive confidentiality between themselves. E.g., Am. Special Risk Ins. Co. v, Delta Am. Ins. Co., 634 F. Supp. 112, 121 (S.D.N.Y. 1986). 
Confidentiality: No confidentiality duty to Investor would prevent her from giving material information to Founder. ${ }^{15}$

Fiduciary Duty: She would have a duty to inform Founder of the accountant's statement. ${ }^{16}$

The lawyer's duties to joint clients are clearer than those to organizations. They stand nearly opposite to those duties suggested by the cases on organizational representation discussed in the last Section.

Why should joint and organizational representation be treated so differently? The doctrine offers no ready answer, and it is surprisingly difficult to formulate one from scratch. One explanation can be dismissed. There is a tendency to assume that organizations involve large numbers of constituents, most of whom have no direct contact with the organization's lawyers, while joint representation involves small numbers of people in direct contact with the lawyer. It might seem that, once the numbers get large enough, it would become impossible for an attorney to give each constituent the kind of attention that the joint-representation model contemplates. Obviously, however, these assumptions are often inapplicable. The corporate structure in the Founder Freeze-Out scenario exemplifies a large class of small business clients that comprise small numbers of people. There is no practical obstacle to the lawyer considering their interests individually.

Moreover, it would be wrong to assume that, even where the lawyer must be concerned with numbers of people too large for detailed individual attention, treating them as entities in the manner we are discussing is the only plausible option. A model of joint representation has been successfully applied to large groups-the class action. Classes can number in the thousands; indeed they often include the shareholders of public corporations. Yet many consider class representation to be a form of joint representation, and the courts sometimes treat them as such for professional responsibility purposes. Lawyers are sometimes forbidden to continue representing an entire class once conflict develops among its members; confidentiality usually does not limit the lawyer's ability to disclose information material to members of a class, and lawyers have affirmative duties of disclosure to individual class members. ${ }^{17}$

15. Model Rules, supra note 1, at R. 1,9 (no confidentiality between joint clients).

16. E.g., Model Rules, supra note 1, at R. 1.4 (requiring that the lawyer provide clients with information necessary for "informed decisions regarding the representation").

17. See John C. Coffee, Jr., Class Action Accountability: Reconciling Exit, Voice, and Loyalty in Representative Litigation, 100 COLUM. L. REv. 370, 380-85 (2000) (arguing that class representation is best understood as joint- "aggregate"--representation rather than as entity representation). There is an emerging view to the contrary. See, e.g., David Shapiro, Class Actions: The Class as Party and Client, 73 Notre Dame L. Rev. 913 (1998) (arguing for "entity" view). Courts have shown some tendency to depart from joint-representation norms with respect to class conflicts of interest, though the issues remain controversial. Compare In re Derivatives Antitrust Lit., 748 F.2d 157, 161 (3d Cir. 1984) (disqualifying class counsel from representing either faetion in intraelass dispute: court treats case as 
Another rationale for differential treatment of joint and organizational representation is implied consent. By formally associating themselves in an organization, such as a corporation, constituents indicate that they desire and expect to submerge their individual interests in an entity. Legal representation in accordance with the entity model is one of the entailments of formal organization. But this explanation, too, has deficiencies.

The consent rationale misapprehends the psychological reality of, at least, many small business organizations. Legally, incorporation typically occurs through the filing of papers of which most constituents may not even be aware. They may think of incorporation primarily as a means of limiting liability or gaining tax advantage, and they may not think of it as affecting internal relationships at all. Constituents who deal directly with business counsel may think of her as their lawyer in precisely the way that jointly represented individuals do. Such concerns have led several courts in suits between constituents of close-corporation constituents to apply partnership norms of mutual fiduciary duty. Cases like Wilkes $v$. Springside Nursing Home ${ }^{18}$ ignore corporate formality in defining internal duties among constituents and hold them to strong duties of loyalty to each other as individual collaborators.

Another problem with the consent rationale is that formal consent, the only kind of consent that can be presumed in the organizational context, is emphatically insufficient for joint representation under established doctrine. Joint representation requires informed consent, which connotes both explicit individual manifestation of agreement and genuine understanding. ${ }^{19}$ Even explicit consent given after considerable advice may be held insufficient if it later appears that an important contingency was not foreseen. Yet, thc implied constituent consent that suffices for organizational representation requires neither individual assent nor understanding.

\section{B. Piercing the Veil for Professional Responsibility Purposes}

One possible response to the foregoing doctrinal mystery is to deny that organizational representation should be treated differently from joint representation at all. A few cases treat corporate representation as

tantamount to where "two clients retained the same law firm to file suit"), with Lazy Oil v. Witco Corp., 166 F.3d 581, 591 (3d Cir. 1999) (reaching different results in similar situation: jointrepresentation rules cannot be "mechanically applied" to class actions).

18. 353 N.E.2d 657 (Mass. 1976); see also Rosenthal v. Rosenthal, 543 A.2d 348 (Me. 1988); Donahue v. Rodd Electrotype Co., 328 N.E.2d 505 (Mass. 1975).

19. MODEL RULEs, supra note 1, at R. 1.7. Even informed consent is not sufficient. The Rules require, in addition, that the lawyer reasonably determine that joint representation will not adversely affect either clicnt's interests. The contrast to organizational reprcsentation is striking. Once constituents acquire the status of an organization, the Rules are silent about the lawyer's responsibility for constituent understanding or welfare. 
tantamount to joint representation, essentially "piercing the corporate veil" for ethical purposes.

In some cases, the issue is whether corporate counsel is disqualified from representation adverse to a constituent of the corporation. In Woods $v$. Superior Court, ${ }^{20}$ counsel for a corporation wholly owned by a husband and wife was disqualified from representing the husband in a divorce action against the wife. The court treated the wife as a current client: "[I]n representing an ongoing family corporation, [counsel] in a very real sense continues to represent [the] wife." ${ }^{21}$ Two Oregon cases arising from control contests in family corporations reach similar results. "[T]he attorney in such a situation represents the corporate owners in their individual capacities as well as the corporation unless other arrangements are clearly made," one concludes. ${ }^{22}$ And in a case disqualifying corporate counsel from appearing in an action between its only two shareholders, the Southern District of New York wrote that "it is indeed reasonable for each shareholder to believe that corporate counsel is in effect his own individual attorney. $" 23$

In other cases, the issue is whether those in control of the corporation can invoke attorney-client privilege to prevent interrogation of corporate counsel in litigation with a constituent. In another husband-wife corporation case, a California court held the privilege inapplicable. ${ }^{24}$ The court characterized the entity as "akin to a partnership in its informality." 25

In Opdyke v. Kent Liquor Mart, ${ }^{26}$ the Delaware chancellor applied the joint-representation approach to an issue of substantive liability. The lawyer purchased the sharcs of two of the entity's three sharcholders, knowing that the third wanted to buy them. Clcarly, the lawycr's fiduciary duties to the corporation precluded him from taking a "corporate opportunity"

20. 197 Cal. Rptr. 185 (Cal. Ct. App. 1983).

21. Id. at 188.

22. In re Brownstein, 602 P.2d 655, 657 (Or. 1979); see In re Banks, 584 P.2d 284 (Or. 1978).

23. Rosman v. Shapiro, 653 F. Supp. 1441, 1445 (S.D.N.Y. 1987). For a case applying the approach to a large organization, see Westinghousc Elec. Corp. v. Kerr McGee Corp., 580 F.2d 1311 (7th Cir. 1978) (counsel for trade association disqualified from representation adverse to association mcmber whose counsel had received material confidences from the member).

24. Hecht v. Supcrior Court, 237 Cal. Rptr. 528 (Cal. Ct. App. 1987). The court seems to bc invoking the conception of partnership as an aggregate of discrete individuals. Partnerships are sometimes treated as entities, and the lawyer's duties in the partnership context are no clearcr than they are in the corporate one. See infra Part Vll.A.

An approach contrary to Hecht was taken in Hoiles v. Superior Court, 204 Cal. Rptr. 111 (Cal. Ct. App. 1984), where the court applied the corporate attorney-client privilege to bar a minority shareholder suing derivatively from discovering attorney-officer communications, even though the corporation was entirely owned and informally run by a small number of family members. The case seems especially implausible because the corporate attorney had represented some constituents in purely individual matters, and many of the allegedly privileged communications involved nonshareholder family members.

25. Hecht, 237 Cal. Rptr. at 565.

26. 181 A.2d 579 (Del. 1962). 
without consent, but the court apparently considered that no interest of the corporation was harmed by the lawyer's action. ${ }^{27}$ The court, nevertheless, held that the lawyer owed a comparable duty to the individual shareholder. It emphasized the informality of the business and characterized the lawyer as "attorney for three joint adventurers." 28

It is unclear to what extent the decisions in these cases depend on personal contact between constituents and the lawyer. To the extent they do, the holding against the abused shareholder in Skarbrevik might be distinguishable, since there is no indication that the lawyer-defendant there had had direct contact with the plaintiff. On the other hand, it is equally arguable that the joint-representation treatment in these cases is grounded less on personal contact between lawyer and constituents than on the naturc of the businesses, especially on the small numbers of stakeholders and their informal relations with each other. These are the factors on which the Wilkes line of cases bases its imputation of fiduciary duties among constituents, and they would seem equally relevant to the question of attorneyconstituent duties.

The Wilkes line of cases emphasizes that small business constituents do not have much sense of a distinction between individual interests in the business and corporate interests (and few lawyers would be able to give them a coherent explanation of the distinction). ${ }^{29}$ Most constituents will have some sense of the danger of conflict, but they are more likely to view the lawyer as someone who, in such situations, will take an active role in trying to resolve the problem on terms that are fair to everyone. Many will likely feel betrayed if the lawyer appears to side with other constituents against them. ${ }^{30}$

\section{Intermediate Responses}

Some alternative approaches that reduce the distinction between joint and organizational representation have been suggested.

27. Id. at 583 .

28. Id.

29. Wilkes v. Springside Nursing Home, 353 N.E.2d 657 (Mass. 1976); see also In re Banks, 584 P.2d 284, 292 (Or. 1978) (stating that in these situations, "there is no real reason for [a constituent] to differentiate in his mind between his own and corporatc interests").

30. The logic of cases such as Wilkes and Donahue v. Rodd Electrotype Co., 328 N.E.2d 505 (Mass. 1975), imputing fiduciary duties among close-corporation participants, supports the jointrepresentation approach for a lawyer's duties to constituents. However, the cases do not consistently find that attorneys have duties to constituents in situations where constituents have strong duties to each other. For example, in all jurisdictions, general partners owe fiduciary duties to their partners, but some courts have held that partnership lawyers owe no duties to individual partners. See Richter v. Van Amberg, 97 F. Supp. 2d 1255 (D.N.M. 2000); Rice v. Strunk, 670 N.E.2d 1280 (Ind. 1996). While cases applying the joint-representation approach to close corporations tend to explain their results by describing the business as "akin to a partnership," Hecht, $237 \mathrm{Cal}$. Rptr. at 531, at least one case applying the entity approach to a partnership explains its result by saying that partnerships are "analogous" to corporations. See Rice v. Strunk, 632 N.E.2d 1151, 1152 (Ind. Ct. App. 1994). 


\section{1. "Reasonable Expectations" and Additional Representation}

Even in large corporations, where the corporate attorney leads a constituent to believe that she is acting as the constituent's individual lawyer, the courts will impose on the attorney professional responsibilities to the constituent. In one well-known case, for example, corporate counsel accompanied an officer to a Securities and Exchange Commission hearing and said nothing when the officer identified him as his personal lawyer. ${ }^{31}$ When the corporation subscquently sued the officer over the same matter, the court treated the officer as a former client and disqualified the lawyer from appearing for the corporation. ${ }^{32}$

Unlike the "piercing" cases, these do not speak of joint constituent representation as corporate representation. Rather, they speak of constituent representation in addition to corporate representation. The cases are a plausible response to two special situations. In the first, the corporation agrees to provide representation to a constituent. In the second, corporate counsel carelessly leads' a constituent to misunderstand the limits of the lawyer's undertaking. In the former case, the constituent duty arises from the agreement; in the latter, it arises from the lawyer's carelessness, which is attributable to the organization as the lawyer's principal.

However, this doctrine has also been interpreted more broadly as a general approach to the issue of constituent duties in organizational rcpresentation. Under this approach, whether the organization's lawyer owes duties to a constituent depends solely on the "reasonable expectations" of the constituent based on the constituent's dealings with the lawyer (or perhaps other agents of the organization). Some opinions involving partnerships and trade associations could be read to take a view like this, and one commentator has suggested that this doctrine should be applied to organizations generally. ${ }^{33}$

The "reasonable expectations" approach would support constituent duties only in a limited range of situations. First, it depends on direct

31. E.F. Hutton v. Brown, 305 F. Supp. 371 (S.D.Tex. 1969).

32. Id.; see also Meehan v. Hopps, 30। P.2d 10 (Cal. Ct. App. 1956).

33. E.g., Security Bank v. Klicker, 418 N.W.2d 27, 31 (Wis. Ct. App. 1987) (finding that partnership lawyer owed no duty to individual partner where there was no evidence that he "believed Snell represented him" individually); ABA Standing Comm. on Ethics and Prof'l Responsibility, Formal Op. 92-365 (1992) (applying something like the "reasonable expectations approach" to whether a trade association lawyer owes duty to members); ABA Standing Comm. on Ethics and Prof'l Responsibility, Formal Op. 91-361 (1991); BNA/ABA LAWYER's MANUAL on Professional CONDUCT 1001: 110, 113 (1992) (stating partnership lawyer docs not "represent" individual partners for conflicts purposes unless factors such as "partner's cxpectations of personal representation" indicate additional undertaking); Note, An Expectations Approach to Client Identity, 106 HARv. L. Rev. 687 (1993) (generalizing expectations approach as a response to qucstions of constituent duty). Further pertinent authority is reviewed and discussed in Nancy J. Moore, Expanding Duties of Attorneys to "Non-Clients": Reconceptualizing the Attorney-Client Relationship in Entity Representation and Other Inherently Ambiguous Situations, 45 S.C. L. REv. 659, 687-95 (1994). 
reliance-inducing conduct by the lawyer. The constituents in Skarbrevik or our Founder Freeze-Out hypothetical would have no claim if they had not dealt personally with corporate counsel.

Second, it would tend to deny constituent duties in situations of manifest intraorganizational conflict. The requirement that the expectations be "reasonable" will be most readily established in situations where conflict either is not perceived or seems remote at the time the expectations are formed. Where conflict is clear and strong at the outset, it seems likely that the constituent's expectations will be held unreasonable. (Consider a version of the Founder Freeze-Out example in which Founder first encounters the lawyer after the Investor-dominated board has sought his removal.) Doctrine generally declines to base duties on a plaintiff's reliance on someone whose interests are manifestly "adverse" to hers. ${ }^{34}$ Thus, a proponent of the "expectations approach to client identity" argues that the minority shareholder in Felty v. Hartwig, one of the freeze-out cases resembling our hypothetical, could not reasonably have expected assistance from corporate counsel because his interests were adverse to the corporation. ${ }^{35}$

However, since the expectations approach offers no understanding of the interests of the organization, it yields no explanation for either of these limitations. Without some understanding of the organization's interests, we have no basis for rejecting the claim by the constituent who had no expectation of individual representation but who claims that the lawyer's duty to the organization required the lawyer to protect some interest of his. Similarly, without some understanding of the organization's interests, there is no way to make a judgment as to whether the constituent's interests are "adverse" and hence whether the expectations are "reasonable."

The expectations approach is thus either incomplete or implausible. It is incomplete to the extent that it purports to address whether the lawyer owes duties to the constituent in addition to the, organization without first asking whether she owes duties to the constituent by virtue of her duties to the organization. The approach also is implausible to the extent that it incorporates the tacit identification of organizational and managerial interests of cases such as Skarbrevik.

34. See, e.g., Garcia v. Rodey, Dickason, Sloan, Akin \& Robb, 750 P.2d 118, 122 (N.M. 1988) (holding that reliance on statement of opposing lawyer in litigation is not reasonable).

35. See supra note 33.

36. There are similar problems with the claim that corporate counsel owes a duty to constituents because constituents are "third-party beneficiaries" of the contract to provide legal services to the organization. Where the corporation contracts explicitly for counsel to provide legal services to constituents, there is no reason not to enforce the contract. E.g., Kelly v. Kruse, Landa, Zimmerman \& Maycock 199l U.S. App. LEXIS 19742, at *7 (10th Cir. August 20, 1991) (unpublished). However, courts routinely refuse to imply third-party beneficiary status merely from the claimant's status as a corporate constituent on the ground that the corporation's contractual intent is too ambiguous. E.g., Skarbrevik v. Cohen, England \& Whitfield, 282 Cal. Rptr. 627 (Cal. Ct. App. 1991). 


\section{Aiding and Abetting Liability}

Some cases have held that a lawyer who assists managers in conduct that breaches managers' fiduciary duties to constituents is liable to the constituents for "aiding and abetting" the managers' breach. ${ }^{37}$ For example, the Oregon Supreme Court in Granewich v. Harding ${ }^{38}$ approved an aiding-andabetting theory on allegations of a wrongful freeze-out resembling those in Skarbrevik. One of the three principals in a close corporation alleged that the other two breached fiduciary duties in diluting his ownership by issuing shares to themselves, removing him without cause from the board, and terminating his employment without cause. The court indicated that corporate counscl could be liable both for providing strategic advice to the two manager defendants and for failing to inform the plaintiff of their activities.

As far as it goes, this approach seems strongly supported. Longstanding tort principles prescribe liability for one who knowingly provides substantial support to another's breach of a tort duty. ${ }^{39}$ There is no reason to exclude lawyers from such liability. The objection that fiduciary duty is often unclear can be met by interpreting the requirement that the support be provided "knowingly" to entail that the primary actor's breach be a clear one. Skarbrevik and Granewich are examples; the courts treated the managers' conduct in both cases as obvious breaches. ${ }^{40}$

Granewich seems right in imposing liability for aiding and abetting, but it goes only part of the way toward answering the questions raised by our Founder Freeze-Out scenario. It is concerned with liability and does not directly address confidentiality and disqualification issues. Moreover, it is not clear that it speaks even to liability when the claim, like the one in our hypothetical, alleges passive nondisclosure rather than active deception or facilitation. The substantial-assistance requirement of the established

37. See, e.g., Granewich v. Harding, 985 P.2d 788, 793 (Or. 1999); see also Thornton v. Evans, 692 F.2d 1064, 1082 (7th Cir. 1982) (attorney who prepared documents facilitating fraudulent fund transfer liable for aiding and abetting breach of fiduciary duty under federal labor law). Contra Koutsoubos v. Casanave, 816 F. Supp. 472, 475 (N.D. IIl. 1993) (noting that "Illinois has never recognized the tort of aiding and abetting a breach of fiduciary duty").

38. 985 P.2d at 788.

39. Restatement (SECOND) OF ToRTs $\S 876$ (B) (1997) [hereinafter Restatement of ToRTs]; Restatement (Second) of Agency $\$ 348$ (1958) [hereinafter Restatement of Agency].

40. Lawyer liability to nonclients for assisting client fraud has occasionally been resisted on the ground that it might interfere with the client trust and willingness to confide. E.g., Shatz v. Rosenberg, 943 F.2d 485 (4th Cir. 1991), cert. denied, 503 U.S. 936 (1992). The argument seems both parochial and obtuse. Doubtless every profession likes to believe that its distinctive purposes are so important that its members should be exempt from ordinary tort duties, but such claims are tainted by pride and self-interest. Moreover, in order to do their jobs, lawyers require not just the confidence of their clicnts, but the willingness of others to trust them not to lie or take lawless advantage. Otherwise, they would be unable to make credible representations and commitments on behalf of their clients. In any event, however much we credit arguments for lawyer exemption in the third-party context, they are irrelcvant or circular in our context, where the question is not the relative importance of client loyalty, but rather who embodies "the client" for purposes of this loyalty. 
tort principle often has been interpreted to require more than silence. ${ }^{41}$ Skarbrevik is, again, an easy case for liability on this point. It appears that the lawyer, in addition to giving advice, was active in preparing and filing fraudulent documents. ${ }^{42}$ Under general tort principles, silence alone does not confer liability unless there is a particular duty to speak. ${ }^{43}$ This simply raises anew the question we hoped to answer in turning to this doctrine.

To the extent that Founder's claim against the lawyer in our hypothetical rests on the latter's failure to report the accountant's statement, it seems viable under the joint-representation approach, which gives the lawyer himself a fiduciary duty to Founder, but not under an aiding-andabetting theory, which would require actively assisting management wrongdoing.

\section{Retroactively Imposing the Corporate Veil}

Instead of extending the joint-representation approach into the traditional realm of organization, we could do the opposite: we could treat individuals traditionally considered jointly represented as entities. In Jesse $v$. Danforth ${ }^{44}$ the Wisconsin Supreme Court took this route for disqualification issues arising from representations involving organizational formation. In that case, twenty-three participants in a business asked the lawyer to incorporate the business and represent it. A partner of the lawyer subsequently represented a plaintiff in a medical-malpractice suit against Dr. Danforth, one of the twenty-three, who had become an officer in the corporation. The defendant sought to disqualify the firm on the ground that Dr. Danforth was either a present client, by virtue of his corporate office, or a former client, as a member of the preincorporation group. While adhering to the conventional view that being an officer of a corporate client does not make one a client, the court broke new ground by applying the entity rule retroactively to the preincorporation group, holding that a member of a

41. See, e.g., Reves v. Ernst \& Young, 507 U.S. 170 (1993) (holding that accountants who gave passive professional advice did not "participate" in firm's fraudulent activities for purposes of RICO liability).

Skarbrevik rejected aiding and abetting liability by invoking the doctrine that liability for aiding and abetting a fiduciary breach arises only when the defendant acted "in furtherance of [his] own financial gain." Skarbrevik, 282 Cal. Rptr. at 639. See also Doctors' Co. v. Superior Court, 775 P.2d 508,513 (Cal. 1989). The strongest rationale for this holding would be to protect good faith (but mistaken) legal advice. However, the holding is subject to criticism on two grounds. The general requirement that the defendant have "knowledge or scienter" that the primary actor's conduct is wrongful should largely accomplish this purpose without inquiry into gain. Moreover, the Skarbrevik lawyers were being compensated by hourly fees and were probably acting in the hope of preserving a relation that would generate fees in the future. This ought to constitute "personal gain." See Weingarten v. Warren, 753 F. Supp. 491, 496 (S.D.N.Y. 1990) (holding that receipt of fees from breaching trustee warrants inference that lawyer acted for personal gain).

42. See Skarbevik, $282 \mathrm{Cal}$. Rptr. at 632.

43. E.g., RESTATEMENT OF TORTS, supra note $39, \S 551$.

44. 485 N.W.2d 63 (Wis. 1992). 
business group that seeks assistance in incorporation is not to be treated as an individual client for conflicts purposes. ${ }^{45}$

The holding seems appropriate to the facts of the case. The group was larger than those involved in most joint representations. Moreover, it appears that the malpractice claim arose from activities unrelated to the business that the firm had represented; so even if Dr. Danforth had been deemed a former client, under the Model Rules there might have been no basis for disqualification. ${ }^{46}$

On the other hand, the court's broad formulation, which would ostensibly apply the retroactive entity rule even to intrabusiness disputes among constituents in smaller, more informal organizations, seems dubious. The court apparently relies on the fact that individuals seeking incorporation expect and desire to be dealt with on a more formal basis. But, as we have noted, the overwhelmingly salient reasons for small business incorporation concern dealings with outsiders, such as liability protection or ease of contracting or holding property. There is no reason to assume that the consequences such individuals desire include a transformation in their internal relationships.

As a general approach to corporate disqualification issues, the retroactive approach seems either superfluous or unsatisfactory. It is superfluous where the conflict arises between a constituent and a third party. There, the substantial-relation test will usually produce the same result whether or not the entity approach is used. It is unsatisfactory where, as in the Founder Freeze-Out scenario, the dispute is between constituents. Applying the retroactive entity approach in that situation yields an immediate, clear answer only if we conflate corporate interests with those of the current control group, and I have argued that this is improper. ${ }^{47}$

\section{Id. at 67 .}

[W] here (1) a person retains a lawyer for the purpose of organizing an entity and (2) the lawyer's involvement with that person is directly related to that incorporation and (3) such entity is eventually incorporated, the entity rule applies retroactively such that the lawyer's pre-incorporation involvement with the person is deemed to be representation of the entity, not the person.

Id.

46. Model Rules, supra note 1, at R. 1.9(a) (requiring consent for representation adverse to former client where matter is "the same or a substantially related" to substance of prior representation).

47. Still another alternative is a proposal by Lawrence E. Mitchell, Professional Responsibility and the Close Corporation: Toward a Realistic Ethic, 74 ConNell L. Rev. 466 (1989). Mitchell would treat close-eorporation representation as joint representation of the shareholders, but he would apply a strict conflict-of-interest rule that would require separate representation in a broad range of cases. Under this rule, there could be no joint (or entity) representation of constituents unless certain conditions reducing the likelihood of conflict were satisfied. Either the shareholders must all have inherited their shares from a single founder, or there must be a majority shareholder, and the articles must clearly define the rights of all share classes.

This seems far too strict. Having pointed out the arbitrariness of the conventional distinction between joint and organizational representation, Mitchell reintroduces it in a less expansive but equally arbitrary form. Outside the organizational context, the bar's joint-representation rules provide a good 


\section{Conclusion}

Some may find the arguments for the joint-representation approach implausible. Moreover, the ones I have presented are not applicable to largc, impersonal businesses. To the extent that we find the jointrepresentation approach inadequate, we will be inclined to consider the entity approach either as an alternative or a supplement to joint representation. We have yet to see what the entity approach involves. In fact, there is no single understanding of the entity approach; thcre are at least three variations. An adequate analysis of intracorporate conflicts must draw on all three. Once formulated plausibly, the entity approach turns out to be considerably less different from the joint-representation approach than conventional rhetoric presumes.

\section{III}

\section{Entity Representation I: The Organization as Control Group}

The first interpretation of entity representation conflates the corporation with those who have dc facto control of it and the corporation's interests with the interests of the control group. The control group will usually be the group of officers or inside dircctors with whom the lawyer routinely deals.

The "Control Group" view gives definite answers to most of the questions raised by the Founder Freeze-Out scenario. After Founder has been squeezed out, Investor is in control, Investor's interests become the corporation's interests. It is in Investor's interests for the lawyer to defend against any claims Founder might make, so the lawyer is not disqualified. It is against Investor's interests for Founder to find out about the accountant's statements, so confidentiality forbids disclosure. And the Investorcontrolled board can invoke the attorney-client privilege against Founder. ${ }^{48}$

Although few lawyers recognize or embrace this model as an explicit principle, we have seen that it is the tacit premise of cases holding that the corporate lawyer violates no professional duty in assisting managers in flagrantly ultra vires conduct that injures noncontrolling shareholders or that management may routinely invoke the attorney-client privilege against a

deal of flexibility in taking account of the costs and benefits of joint representation. A lawyer can jointly represent even interests in open conflict if she gets informed consent and reasonably believes it is in the interests of the parties. And it is often reasonable to so believe. In addition to reducing lawyer fees, joint representation can often dampen conflict by strengthening trust, facilitating the exchange of information, and precluding bluffing and aggressive posturing. Mitchell's rule would often preclude constituents from choosing this option even when there is no actual or antieipated conflict among them.

48. Prior to the time Investor becomes a shareholder, Founder has control. At this point, it is in Founder's interests for the lawyer to discuss the future dangers of a squeeze-out, so lawyer should do this.

1 have heard lawyers suggest that it is not in the corporation's interest for Founder to get this advice, even when he is the only officer or shareholder. They appear to be anticipating Investor's control. 
derivative plaintiff. When courts characterize constituents alleging unlawful conduct on the part of the control group as adverse to the corporation, they are conflating the corporation with incumbent management. ${ }^{49}$

A case that comes close to explicit espousal of the Control Group model is Bell v. Clark, ${ }^{50}$ in which the Indiana Supreme Court held that a lawyer for a limited partnership had no duty to inform limited partners of wrongdoing by the general partner. The court held that a partnership lawyer is answerable only to the partners who have managerial authority:

To the extent that a partnership agreement places responsibility for the management of the partnership in the hands of less than all the partners, those partners to whom management responsibilities have been given become the "duly authorized constituents" [entitled to instruct the lawyer]. ${ }^{51}$

Since both the agreement and the statute gave managerial responsibility to the general partner, the lawyer was answerable only to him. The opinion is indifferent to the fact that the general partner allegedly violated limitations on his conduct imposed by both the agreement and the statute. Its use of "authorized" is thus a term of art. According to this vicw, holding office, rather than authority, characterizes the organization.

This view is grounded in powerful psychological forces. An organizational lawyer can only deal with her client through agents. If she has recurring dealings with particular agents, she is likely to develop personal relations with them. Apart from these relations, the client as an entity remains a remote and ambiguous abstraction. Other corporate constituents are faceless and silent. Relations with particular managers will be the most concrete, vivid, and emotionally engaging dimension of the lawyer's work for the client. There is thus a natural psychological tendency to identify the client with these personal relations.

This psychological disposition is reinforced by other factors. If the managers are senior officers, they will have broad authority over corporate affairs, so the psychological identification substantially overlaps the legal one. More than likely, these officers will have chosen to employ the lawyer and will make decisions about her future employment. Self-interest encourages the lawyer to identify these officers as the entity. Finally, professional responsibility rhetoric tends to speak of clients as persons and, even when it distinguishes organizational clients, to speak of them as unitary entities, thus obscuring possible conflict.

49. E.g., Skarbrevik v. Cohen, England \& Whitfield , 282 Cal. Rptr. 627, 637 (Cal. Ct. App. 1991) (noting the plaintiff was a "potential adverse party whose interests could not be, and were not, represented by his adversaries' chosen counsel [that is, corporate counsel], whose duty of loyalty was to his own clients"); Felty, N.E.2d at 557.

50. 670 N.E.2d 1290 (lnd. 1996).

51. Id. at 1293 . 
This tendency is also reinforced by the fact that personifying the corporation in terms of its agents is a useful cognitive and legal device across a broad range of situations in which the lawyers assist managers in dealing with outsiders on behalf of the corporation. In these situations, the legal fiction that treats the corporation as a unified, organic entity rests in part on the shared interest of its constituents in enhancing its value. There is good reason to presume in this situation that those in control will act on behalf of this interest. To be sure, there may be differences among constituents about the best way to pursue their shared interest, and constituents may sometimes have selfish interests that may bias their judgments, but where there is no manifest disagreement and no apparent conflict of interest, it is reasonable to presume that those in control are serving the shared interest. The same considerations that underpin the "business judgment rule," which prescribes deference to disinterested managerial judgments in shareholder suits, ${ }^{52}$ and the apparent-authority doctrine in agency law, which presumes that a manager has the authority conventionally exercised by those who hold her position, support the lawyer's tendency to identify the corporation with management in considering her professional responsibilities. ${ }^{53}$

However, the grounds for the identification erode when the managers are dealing, not with an outsider on behalf of an apparently unified group of constituents, but with or on behalf of insiders in situations of conflict. Managerial self-interest is less likely here to coincide with legitimate constituent interests.

In the intracorporate situation, the Control Group perspective is subject to the obvious objection that it confuses power with right. It is unreasonable to view the interests of those with de facto control as those of the corporation without regard to how they attained control or how they are using it. The approach resembles those versions of legal positivism that identify law with the pronouncements a sovereign, a view that $\mathrm{H}$. L. A. Hart conceded would make law indistingnishable from the commands of a well-armed thug. ${ }^{54}$

Decisions in conflict cases that invoke the Control Group principle are often either insupportable, as in Skarbrevik ${ }^{55}$ or supportable only on the basis of some other principle, such as the "Authority Structure" principle I address in the next Part. ${ }^{56}$

There may, however, be a range of situations involving conflict where the application of something like the Control Group principle would be supportable. Perhaps the most important candidates involve control

52. E.g., Kamin v. Am. Express, 387 N.Y.S.2d 993 (N.Y. 1976).

53. See Restatement of Agency, supra note $39, \S 8$.

54. H. L. A. HaRT, THE CONCEPT OF LaW 20-25 (1960).

55. See supra note 6 and accompanying text.

56. See discussion infra Part IV. 
contests in public corporations-either proxy battles or hostile tender offers. Corporate counsel routinely assists managers in fighting proxy challenges and hostile takeovers. It seems to be taken for granted that such practice serves legitimate corporate interests. ${ }^{57}$ It is just as commonly assumed that it would be improper for corporate counsel to assist the challenger, even if she felt that the corporation would be better off if the challenge succeeded.$^{58}$ These assumptions are debatable. In all such situations, the challengers assert that the corporation would be better off if management were defeated. Another example occurs where counsel assists management in defending against an anticipated future challenge, for example, by installing antitakeover defenses. Here, management has a strong conflict of interest that raises questions about its ability to speak for the corporation. To be sure, counsel will rarely be in a position to make a reliable judgment on the merits. That limitation, however, does not necessarily suggest commitment to management as a default position. As a matter of logic, it would seem to lead more directly to neutrality.

The promanagement default position might be grounded on a corporate law presumption that continuity of management serves corporate interests. One might infer such a presumption from numerous features of corporate law that advantage incumbents, including privileged access to relevant information, discretion over voting procedures, the ability to finance proxy campaigns from the corporate treasury, and the constraints in securities, banking, and insurance law on large shareholder activism.

Moreover, it is not clear that any purpose would be served by requiring corporate counsel to remain passive in these situations. Management would then have to retain its own counsel to whom it would have to provide, at additional expense, all the information already possessed by corporate counsel relevant to the issues. It is also not clear what role would remain for corporate counsel. ${ }^{59}$

57. For a rare explicit discussion, sce ABA Comm'n on Prof'l Ethics, Informal Op. 1056 (1968), which approves assisting management in a proxy contcst, but then adds the familiar question-begging qualification "except in situations where ... the giving of the advice would be contrary to the interests of the corporation."

58. Compare Financial Gen. Bankshares v. Metzger, 523 F. Supp. 744, 765 (D.D.C. 1981), rev'd for lack of jurisdiction, 680 F.2d 768 (D.C. Cir. 1982) (holding corporate counsel breached duty by collaborating with dissident shareholders: "Metzger's duty of undivided loyalty to his client corporation should have been directed toward the advancement of the corporate goals articulated by Middendorf as the incumbent manager"), with In re Wise, 433 Mass. 80, 88 (2000) (approving discipline of nonprofit corporation lawyer who assisted dissidents; describing duty as "to remain neutral"). See also ABA Comm'n on Prof'1 Ethics, Informal Op. 516 (1962) (stating that corporate counsel may not assist dissident shareholders, even if he believes their success would be in the bcst interests of the corporation).

59. Developments in the Law-Conflicts of Interest, 94 HARv. L. REv. 1244, 1335 (1981).

[Requiring separate counsel for management in all situations of conflict] is both unrealistic and wasteful: unrealistic because it ignores the close working relationship between the inhouse attorney and management, and wasteful because it relegates the corporate attorney to a passive or duplicative role in conflicts where no separate "entity intcrcsts" are identifiable. 
The pro-management policy has limits, however. If a presumption is warranted, it has to be a rebuttable one. First, it is routinely conceded that counsel must not assist where management is pursuing a course that is plainly unlawful. ${ }^{60}$ This is not a demanding standard in the control contest area, however, where standards are vague and management has a good deal of discretion. Second, substantial authority requires that corporate counsel remain neutral in some derivative suits. Where the individual defendants include incumbent officers, joint representation is deemed permissible in the early stages of the suit, while the nature of the claims is explored, or where the claims seem patently without merit. ${ }^{61}$ In other situations, however, courts have insisted on separate representation. Some have permitted corporate counsel to represent the officers, while new counsel is retained for the corporation..$^{62}$ More often, courts insist that corporate counsel represent the corporation and that they remain neutral or "passive" toward the derivative officers. ${ }^{63}$ It would be efficient to have corporate counsel assist management in all internal disputes. Counsel is already familiar with the issues and has an established line of communication with management. But the principle of loyalty to the entity is deemed to require the sacrifice of these efficiencies in the derivative context.

What differentiates many proxy or acquisition contests from derivative suits is that the former necessarily involves a specific allegation of breach of fiduciary duty on the part of management. Where such an allegation is not patently without merit, it suffices to overcome the promanagement presumption.

Of course, control contests often involve allegations of breach of fiduciary duty, and are often accompanied by derivative suits. Moreover, even where such allegations have not been made, there may be other grounds for considering the presumption rebutted. If management is engaging in a clear breach of duty, the lawyer should not be permitted to wait for a derivative suit to challenge it before taking responsive action.

A harder case arises in situations like the Founder Freeze-Out example, where the breach is not clear, and there has been no constituent claim, but there probably would be a claim if material information were available to an affeeted constituent. If Founder knew the accountant's statement, he likely would make a claim. If the claim were nonfrivolous, it might be desirable from the point of view of the organization as a whole for it to be

Id.

60. E.g., id. at 1337-38.

61. See In re Conduct of Kinsey, 660 P.2d 660, 669 (Or. 1983); Schwartz v. Guterman, 441 N.Y.S.2d 597, 598 (1981).

62. See Cannon v. United States Acoustics Corp., 398 F. Supp. 209 (N.D.111. 1975), aff'd in relevant part, 532 F.2d 1118 ( 7 th Cir. 1976).

63. E.g., Yablonski v. United Mine Workers, 448 F.2d 1175, 1181 (D.C. Cir. 1971); for a discussion of representation in derivative suits, see infra Part V.B.3. 
asserted, since it would trigger a more reliable process for the resolution of the issue than would otherwise occur. Current management has a strong and specific conflict of interest here, so it makes no sense to accord them the benefit of any presumption.

Some kind of pro-Control Group presumption may help explain why corporate counsel has broad latitude to assist incumbent management in control disputes, but the presumption is only plausible if subject to strong limits. Those limits will have to be supplied by principles of authority and fiduciary duty. These form the basis of the second and third interpretations of the entity idea. Once they have been elaborated, there will be little remaining use for the control group as a distinct interpretation of entity representation.

\section{IV \\ Entity Representation II: The Organization as Authority STRUCTURE}

The second perspective equates the corporation with its authority structure. One way in which a formal organization differs from a collection of individuals is that its constituents have adopted arrangements for allocating power and making decisions. Thus, we could say that the lawyer's duty is to this structure.

\section{A. $\quad$ Model Rule 1.13}

ABA Model Rule 1.13 seems to adopt the Authority Structure perspective in providing that "[a] lawyer employed or retained by an organization represents the organization acting through its duly authorized constituents." Control is not enough; authority is the touchstone.

The rule, however, fails to develop this idea coherently. After asserting the general authority-structure principle, it proceeds to an elaboration that bespeaks confusion and ambivalence. These paragraphs deal with situations in which a corporate agent engages in conduct that is a "violation of law" and is "likely to result in substantial injury to the organization." They offer some vague platitudes about acting in the "best interests of the corporation," then suggest that the lawyer "may" go over the agent's head to the "highest authority that can act in behalf of the organization." They conclude that if the "highest authority" behaves unlawfully, the lawyer "may" resign.

This formulation has some salient deficiencies. First, one would expect that it would always be in the organization's interests for the lawyer to report "unlawful" conduct likely to inflict "substantial injury" on the organization to an agent's superiors, where the agent persists after remonstrance by the lawyer. If disclosure were in the corporation's interests, one would think that the lawyer would have a duty to disclose under any 
interpretation of organizational representation. Yet, the rule speaks of this only as something the lawyer "may" do. ${ }^{64}$

Second, when the "highest authority" in the organization insists on a "clearly" illegal and injurious course of action, the only option under the rule seems to be resignation. ${ }^{65}$ The rule provides this only in a roundabout way (here, as elsewhere, circumlocution signals ambivalence and dissensus within the bar). It does not specifically preclude further disclosure; it simply says that the lawyer "may withdraw." Nevertheless, when the rule is glossed in the light of its legislative history and the related confidentiality rule, ${ }^{66}$ the most likely infcrence is that the lawyer may not do anything else. In particular, she may not make disclosures to corporate constituents other than the "highest authority" or to public authorities. ${ }^{67}$

The disclosure limitation seems inconsistent with the general authority-structure principle with which the rule begins. That principle holds that the lawyer represents the organization acting through its "duly authorized" constituents. Even the highest authority, when it engages in an injurious and "clearly" illegal course of conduct, is not "duly authorized." If it lacks authority to engage in the conduct, then it lacks authority to instruct the lawyer to remain passive about it. Thus, the lawyer cannot look to the highest authority to express the corporation's interests. On what basis then do the Rules assume that passivity would be in the corporation's interests? The drafters are silent on this point.

64. The Sarbanes-Oxley Act of 2002 makes disclosure mandatory for publie corporation counsel in some of the situations addressed by Model Rule 1.13. If the wrongdoing involves a material violation of the seeurities laws or a breach of fiduciary duty, counsel must report it to the chief legal officer or chief executive officer, and if there is no appropriate response at that level, to the audit committee of the board or another committee composed solely of independent directors. Pub. L. No. 107-204, 116 Stat. 745, $\S 307$ (2002) (codified as amended at 15 U.S.C. $\$ 7245$ (Supp. 2002)).

65. Again, resignation is merely an option, not a duty. But see Model Rules, supra note 1, at R. 1.16(a)(1) (stating that a lawyer "shall withdraw" if the representation will result in a violation of law).

66. Id. at R. 1.6.

67. The drafters of the Model Rules proposed initially to permit whatever disclosure was required by the best interests of the organization, but the House of Delegates rejected this proposal. See Stephen Gillers, Model Rule 1.13(c) Gives the Wrong Answer to the Question of Corporate Counsel Disclosure, 1 Geo. J. Legal Ethics 289, 291 (1987). Four states-Maryland, Michigan, New Hampshire, and New Jersey-have enaeted versions of the rule with disclosure permission resembling the initial draft Stephen Gillers \& Roy D. Simon, Regulation of Lawyers: Statutes and Standards 145 (1998). The dominant view among practitioners and commentators seems to be that under the official draft, disclosure is not permitted beyond the board. See, e.g., Robert Tuttle, The Fiduciary's Fiduciary: Legal Ethics in Fiduciary Representation, 1994 U. ILL. L. REv. 889, 924-25, n.190. But there have been dissents. See Geoffrey C. Hazard, JR. \& W. William Hodes, The Law of LAWYERING 17-14, illus. 17-3 (3d ed. Supp. 2002) (suggesting that close-corporation counsel might be warranted in disclosing control-group wrongdoing to shareholder); RESTATEMENT OF THE LAW GoverNing LAWYERS, supra note $2, \S 96, \mathrm{cmt} . \mathrm{f}$ (2001) (noting that the "view of the Reporters [is that the Rule] should not be understood to preclude controlled [outside] disclosure where ... disclosure would clearly be in the interest of the entity client"). 


\section{B. Beyond the Board?}

A further issue concerns the interpretation of "highest authority." In corporations, this is usually the board. Many lawyers tend to conflate the authority structure with the board and operate on the general principle that, when they encounter intracorporate conflict, they should look to the board for instruction. This can be a useful presumption, but it is not categorically valid. As the rule's comments acknowledge, "applicable law may prescribe that under certain conditions highest authority reposes elsewhere." ${ }^{\prime 8}$ The comments mention as an example that special responsibility for some corporate decisions is conferred on independent directors.

Curiously, the comments do not mention shareholders as potentially the "highest authority," although they have responsibility for some important decisions. The question thus arises whether the "highest authority" should include shareholders when the relevant course of conduct could only be authorized by shareholders.

Skarbrevik is an example. ${ }^{69}$ The Articles amendment eliminating the plaintiff-minority shareholder's preemptive rights required shareholder approval. The defendants were seeking to avoid this procedure. Shareholders could waive a meeting only with notice and unanimous consent. Thus, the Authority Structure principle suggests that the lawyer should have looked to the body of shareholders to determine the corporation's interests, and as a practical matter, this required informing the fourth shareholder of the situation. This would be the best way to respect the role of shareholders, notwithstanding the court's characterization of Skarbevik as "adverse" to the corporation, since there is no competing legitimate interest that would have been jeopardized by doing so.

We might thus elaborate on the Authority Structure principle by suggesting that, where no one with authority is available to instruct the lawyer, her job is to facilitate the processes of authoritative decision. This would usually entail providing information likely to prompt them to trigger the relevant processes to key participants.

This approach would be more difficult to apply with large publicly held corporations, where informing shareholders would often be tantamount to public disclosure. There might be important corporate interests that would weigh against this. Perhaps the information would trigger government prosecution or damage suits by private outsiders or give some advantage to competitors. Yet, even with public corporations, going to shareholders may be an appropriate eourse.

Securities and Exchange Commission v. National Student Marketing ${ }^{70}$ a case interpreting lawyers' duties to their clients under the

68. Model Rules, supra note 1, at R. 1.13, cmt. 4.

69. See Skarbrevik v. Cohen, England \& Whitfield, 282 Cal. Rptr. 627 (Cal. Ct. App. 1991).

70. 457 F. Supp. 682 (D.D.C. 1978). 
securities laws, illustrates the application of the Authority Structure perspective in a public corporation context. National Student Marketing and Interstate National, two public companies, agreed to a merger in which Interstate National shareholders would exchange their shares for National Student Marketing shares. At the closing, the lawyers discovered that the "comfort letter" from National Student Marketing's accountants required by the merger agreement would be qualified by adjustments to the earnings figures disclosed to the Interstate National shareholders in connection with the shareholder vote to approve the merger. The lawyers discussed the matter with some directors (though apparently not the full board), and the "consensus of the directors was that there was no need to delay the closing." "71

The court held that the lawyers violated the antifraud norms of the securities law by proceeding with the closing. ${ }^{72}$. The lawyers should have insisted that proxies be resolicited with disclosure of the new information: "In view of the obvious materiality of the information...the attorneys' responsibilities to their corporate client required them to take steps to ensure that the information would be disclosed to shareholders." 73 The court thus adopts the Authority Structure perspective, but unlike Model Rule 1.13, recognizes that with respect to matters requiring shareholder decision, it may entail duties to go beyond the board.

\section{Limits of the Authority Structure Perspective}

In a case like Skarbrevik, where the lawyer participates in the violation of a specific rule allocating authority, the application of the Authority Structure perspective is straightforward. However, many situations are more ambiguous, not only because authority norms can be ambiguous, but also because the distinction between authority norms and other kinds of norms may not be clear. Indeed, any decision by a corporate manager that violates some norm might be called unauthorized.

To cabin the Authority Structure approach, we might focus on procedural, as opposed to substantive, norms. The distinction is often readily

71. Id. at 694 .

72. Id. at 717 .

73. Id. at 713 .

The fact that shareholder claims under the securities acts are termed "direct" rights of shareholders, while most state law fiduciary-duty claims are termed "derivative" rights of the corporation, should not distinguish National Student Marketing from cases like the Founder Freeze-Out scenario. The line between direct and derivative shareholder actions has been drawn largely for procedural purposes and is arbitrary and anachronistic even within that sphere. See infra discussion Part V.C.3. There is no reason to interpret the common law and the securities statutes to ascribe different substantive concepts of corporate obligation. The courts usually interpret the two bodies as in pari materia. E.g., Dirks v. Sec. and Exch. Comm'n, 463 U.S. 646, $654-57$ (1983). Note that in enforcing the securities acts, the National Student Marketing court speaks of the defendants' duty to "their corporate client." National Student Marketing, 457 F. Supp. at 713. 
intelligible. Rules saying that preemptive rights can only be eliminated through an amendment to the Articles of Incorporation and that such an amendment requires a shareholder vote seem clearly proceduraI. Moreover, a major strategy of corporate law is to rely on procedural norms to avoid judicial resolution of difficult substantive decisions. Most important internal substantive norms are subsumed under the fiduciary duties of care and loyalty. The business-judgment rule focuses duty-of-care review on considerations such as the extent of efforts to seek information and of deliberation. ${ }^{74}$ The ratification statutes focus duty-of-loyalty review on disclosure to and ratification by disinterested directors. ${ }^{75}$ Both tend to turn substantive issues into procedural ones. The Authority Structure approach to professional responsibility seems consistent with the strategy of judicial control that focuses on procedural regularity.

Nevertheless, this approach will be hard to apply to the extent that the intracorporate dispute is about authority itself. This is explicitly the case in the Founder Freeze-Out story. The issue is whether Investor is entitled to control the board. That, of course, depends on the merits of Investor's claim that the milestones have not been met. To assume that the current board has authority to instruct the lawyer is to adopt Investor's position on the merits.

Of course, if the lawyer were to disclose the aceountant's statements to Founder, Founder would be likely to raise the substantive issue in a lawsuit. Litigation is a default decision-making procedure when the normal corporate processes fail to aehieve agreement. If we viewed shareholder litigation as an extension of the corporate processes, we might conclude that the Authority Structure would support disclosure to Founder. To decide that disclosure is warranted, the lawyer does not need to decide that Founder's claim is meritorious, simply that disclosure will enhance the decision-making process.

However, it would be naive to assume that litigation oriented toward the resolution of authority disputes is always in the interest of the eorporation. Litigation is costly, and it often involves pressures unrelated to the merits of the case. If Founder would be likely to lose the case after imposing substantial legal costs on the corporation, or if he would be likely to force a settlement simply by threatening to impose such costs, it would not be in the eorporation's interests to trigger such a suit. Assessing such contingencies requires some judgment on the merits. The question cannot be answered purely in terms of procedural norms.

Moreover, even if we could somehow decide that the corporation, understood as an Authority Structure, had an interest in the litigation going forward, further issues would arise as to the eonduct of the litigation. For

74. E.g., Smith v. Van Gorkom, 488 A.2d 858, $881-89$ (Del. 1985).

75. E.g., DeL. GEN. CoRP. L. \$144(a) (2002). 
example, can the corporation's lawyer represent the Investor-nominated board members, either alone or with the corporation? If the jointrepresentation perspective is rejected, then Founder cannot claim to be a present or former client, and that is not a ground for disqualification. On the other hand, the corporation has been a client, and if joint representation with the directors is contemplated, it will continue to be a client. Thus, its consent is necessary. The question thus arises as to how the corporation can consent in this circumstance. The control-group approach suggests that incumbent management could consent on behalf of the corporation, ${ }^{76}$ but this ignores management's conflict of interest.

The Authority Structure approach yields no better answer. The Investor directors should not be understood to have authority to make an important corporate decision when they have a severe conflict. On the other hand, the only other constituent-Founder-is equally conflicted. If no consent is possible, then the default position is separate representation for Founder, Investor, and the corporation. But this would entail significant additional costs. If Investor is right on the merits, then separate representation is against the corporation's interests. Again, we cannot assess the issue solely in terms of authority norms.

In general, cases where all or most of the board has a serious conflict will pose difficulties under the Authority Structure principle. The authority of a board in this situation is often ambiguous. A decision by an interested board is usually voidable on the complaint of shareholders unless cither ratified by shareholders after full disclosure or proven "fair." 77 Suppose, however, that management does not seek ratification by the board, and the shareholders do not have enough information to complain. Is such a decision "authorized"? The decision is not clearly unauthorized, at least it is not per se ultra vires. Moreover, the statutes do not require sharcholder authorization; they simply make that one mode of authorization. ${ }^{78}$ The transaction is also legitimate if it is "fair," but here authority depends not on procedures, but on the substantive merits of the decision. It seems likely that in some situations of this type it would be desirable for managers to make disclosurcs to sharcholders. The reasons for this, however, are not fully captured by the Authority Structure idea.

If the Authority Structure perspective is ambiguous where the dispute is about authority, it is incomplete in circumstances where an act that seems procedurally authorized arguably violates substantive rights. An

76. See State Bar of California Standing Comm. on Prof'l Responsibility and Conduct, Formal Op. 1999-153 (stating that board dominated by one of two shareholders can consent to joint representation of dominant shareholder and corporation in derivative suit by minority shareholder). But see the contrary authority regarding derivative suits eited and discussed at notes 62-63, supra, and Part V.C.2, infra.

77. See James D. Cox et al., Corporations 209-15 (1997).

78. E.g., DeL. GeN. Corp. L. § 144(a) (2002). 
important category of cases involves constituents without control rights. Minority shareholders, for example, often lack both board representation and veto rights in a shareholder vote. Nevertheless, they have a right to fair treatment by the corporation and the board. ${ }^{79}$ If the Articles in Skarbrevik $k^{80}$ had not provided for preemptive rights and had authorized a sufficient number of new shares, the dilutive issuances by the majority to itself would have complied with the relevant voting rules. However, if their purpose was simply to transfer value from Skarbrevik to the majority, they were improper. A legal ethic focused on procedural norms would not reach such decisions.

If nonshareholders are considered corporate constituents, then somc of their claims would also not be reached. Internal-control rights are presumptively accorded to shareholders, but some argue that nonshareholder groups such as creditors or workers or local communities should be considered corporate constituencies to which substantive duties are owed. ${ }^{81}$ To the extent that procedural norms do not provide control rights parallel to these substantive ones, the Authority Structure approach does not reach them. ${ }^{82}$

\section{$\mathrm{V}$ \\ Entity Representation III: the Organization as Framework of DEALING}

\section{A. Introduction}

The third understanding of entity representation identifies the corporation with its entire legal framework, including norms about both authority and substantive norms. The corporation derives its unity from a legal structure designed to reconcile the interests of its constituents. The Authority Structure is only part of the full legal structure. In particular, it omits much of the range of fidueiary duties. Understood in terms of its full legal structure, the corporation's identity includes, in addition to a set of decisionmaking procedures, a substantive commitment that its constituents be treated fairly. Thus, a corporation has an interest in the fair treatment of its constituents.

The Framework of Dealing and Authority Structure approaches overlap and will often lead to the same result. Where a particular issue is

79. E.g., Zahn v. Transamerica Corp., 162 F.2d 36 (3d Cir. 1947); Coggins v. New England Patriots Football Club, 492 N.E.2d 1112 (Mass. 1986); Weinberger v. UOP, Inc., 457 A.2d 701 (Del. 1983); Jones v. H.F. Ahmanson \& Co., 460 P.2d 464 (Cal. 1969).

80. Skarbrevik v. Cohen, England \& Whitfield, 282 Cal. Rptr. 627 (Cal. Ct. App. 1991).

81. E.g., Progressive Corporate Law (Lawrence Mitchell ed. 1995); Margaret Blair \& Lynn Stout, A Team Production Theory of Corporate Law, 85 VA. L. REv. 247 (1999).

82. A related category of cases to which the Authority Structure approach seems unresponsive includes situations where the lawyer deals directly with a constituent outside of the authority structure-the situation addressed in Opdyke v. Kent Liquor Mart, 181 A.2d 579 (Del. 1962), and the federal insider-trading rules, see infra Part V.C.1. 
clearly committed to the discretion of a particular constituent or body within the corporation (such as the board), both approaches counsel deference to that constituent. But the Framework of Dealing approach suggests that the lawyer's responsibilities sometimes turn on substantive norms.

For example, in the Founder Freeze-Out scenario, the lawyer might resolve the conflict-of-interest issue by aligning herself with the constituent who had the more meritorious claim. If Founder's claim is valid, the lawyer should represent him; if not, she should continue to represent the incumbent board. Her goal in either case is to represent the corporation. She decides which among the competing claimants speaks for the corporation by determining which claim is most consistent with the Framework of Dealing.

Similar considerations might bear on confidentiality. If the board's substantive position is consistent with the Framework of Dealing, its claim to control the attorney-client privilege is strong. If not, the attorney might feel obliged to make her own judgment as to whether confidentiality is in the corporation's interest. The same applies to fiduciary duties. The lawyer's duties to the corporation should extend to a constituent who has a claim well grounded in the Framework of Dealing. If Founder's claim is valid, and disclosure of the accountant's statement to him will facilitate its assertion, then this approach supports a duty to disclose.

Of course, in many, perhaps even most, situations, the lawyer will not be able to determine reliably the substantive merits. In these circumstances, the Framework of Dealing approach favors neutrality. With respect to the conflict-of-interest issue, this means that the lawycr cannot speak for any of the disputing constituents. She must withdraw. The result is the same as it would be under the joint-representation approach, but the basis for it is different. The joint-representation perspective requires withdrawal because the lawyer cannot adequately represent all individuals and cannot represent any of them individually without jeopardizing duties of confidentiality and loyalty to the others. The Framework of Dealing approach requires withdrawal because the client's interests cannot be determined. ${ }^{83}$ If the lawyer cannot determine the organization's interests, then the premise of treating its constituents as a unity is absent.

With respect to confidentiality, neutrality implies no confidentiality as among constituents. If it is not apparent which constituent speaks on behalf

83. A California ethics committee opinion applies the joint-representation approach to a limited partnership riven by disputes. In that situation, two general partners gave inconsistent instructions to the lawyer, and the partnership agreement did not indicate how such deadlocks should be resolved. In addition, the limited partners sought to remove onc of the general partners, but the agreement gave them the right to do so only on specified grounds, which they asserted and the general partner denied were present. The opinion recommends that the lawyer withdraw. Cal. State Bar Standing Comm. on Prof'l Responsibility and Conduct, Formal Op. 1994-137, in ABA/BNA LAWYERs' MaNuAL ON Prof'L ConduCt (I994). 
of the corporation, then none of them are in a position to invoke confidentiality against the others. With respect to fiduciary duties, neutrality implies no active duties to constituents, including the board, except for ongoing duties of confidentiality vis-à-vis outsiders, and fiduciary duties to protect undisputed corporate interests would continue. Neutrality applies only to the intracorporate dispute.

The Framework of Dealing approach has a strong affinity with Brandeis's notion of "counsel for the situation." Louis Brandeis used this phrase to describe his intervention in the famous Lennox case. ${ }^{84}$ The owner of a troubled tannery business and one of its creditors consulted Brandeis, who already represented another of the business' creditors. The owner insisted that he was committed to repaying all creditors in full. The creditors apparently wanted some assurance against asset stripping or further encumbrances until the debts had been discharged. Brandeis suggested that the business be assigned to one of his partners for the benefit of creditors. His role would be "to give everybody, to the best of my ability, a square deal" and "to see that everybody got his legal rights." ${ }^{85}$ Owner and creditors agreed, but the arrangement broke down when the owner refused to transfer some property to the trustee and the two had a dispute over the owner's claims for compensation for assisting the trustee.

In the resulting dispute, the owner accused Brandeis of violating conflict-of-interest norms. Asked whom he represented, Brandeis replied, "I should say that I was counsel for the situation." 86 The premise of this remark is precisely that of the approach to organizational representation we arc considering. Brandeis's "situation" is a Framework of Dealing-an immanent structure of converging interests constituted by express, implied, default, and mandatory legal terms. The idea has been much derided as a basis for joint representation. ${ }^{87}$ Yet, no one objects to corporate representation simply because constituents have differing interests, and Brandeis's notion is the one that best explains how such representation is possible in circumstances of conflict.

84. Alpheus Thomas Mason, Brandeis: A Free Man's life 232-37 (1956) (describing Lennox).

85. Id. at 233-34

86. Id. at 236 .

87. Seven former presidents of the American Bar Association condemned Brandeis's professional ethics in the Senate confirmation hearings following his nomination to the Supreme Court on the basis of several episodes, including the Lennox case. $1 d$. at 489-90. Many contemporary lawyers agree with the criticism of his conduct in this case. John Frank, for example, concludes a critical appraisal with the advice, "never be "counsel for a situation," explaining, "Lawyers are not retained by situations, and the adversary system assumes that they faithfully represent one interest at a time." John P. Frank, The Legal Ethics of Louis D. Brandeis, 17 STAN. L. Rev. 683, 702 (1965). But lawyers are retained by organizations, and once we recognize that it is a framework of dealing that makes organizational representation possible, we see that such grounding may also be available in circumstances involving formally unaffiliated individuals. 
The Framework of Dealing perspective thus adopts the best theoretical understanding of why the law speaks of the organization as an entity. This does not necessarily mean, however, that it has value as a practical guide to profcssional responsibility decisions. Some will be disturbed by the notion that the lawyer has responsibility for determining the merits of an intracorporate dispute. Some will think she will so seldom be able to make such a judgment that the approach will require ncutrality too often. In fact, however, something like the Framework of Dealing approach seems already presumed by current doctrine in a variety of situations, and it seems to be workable in these and other situations.

I first consider the jurisprudential basis of the Framework of Dealing approach and then turn to its practical application in current doctrine.

\section{B. Jurisprudential Basis}

\section{The Framework of Dealing}

The Framework of Dealing approach provides the most plausible understanding of the "corporation," or more generally, "organization," as we conventionally personify it in lcgal discoursc. The starting point is the recognition that the corporation is a legal fiction. It has no psychology of its own and no moral status of its own. Thus, it cannot have interests of its own. We use the fiction as convenient proxy for the interests of its constituents. We may regard these constituent interests as forming a whole that transcends its parts (an "entity" rather than an "aggregate"), but it remains the case that a corporation's interests are entirely dcpcndent on those of its constituents.

Thus, it makes no sense to spcak of corporate interests that are unrelated or contrary to shared constituent interests. Courts are mistaken, for cxample, when they say, in charactcrizing actions to compcl dissolution as direct rather than derivative, that "an action for dissolution of a corporation cannot possibly benefit the corporation. ${ }^{" 88}$ If a corporation were a natural person, the analogy to dissolution would be suicide, which one might plausibly think is never, or virtually never, in a natural person's interest. But when we think about organizations this way, we have lost our moorings. The only meaningful benefit a corporation can produce is for people, and there are many situations in which the relevant people might benefit from

88. Fontheim v. Walker, 122 N.Y.S.2d 642, 644 (N.Y. App. Div. 1953), affd, 119 N.E.2d 605 (N.Y. 1954); see also Egan v. McNamara, 467 A.2d 733, 738 (D.C. 1983) (holding that in a transaction between a three-shareholder eorporation and its largest shareholder, corporate counsel's responsibility is to protect corporation's "continued existence"). On the othcr hand, some of the cascs arising from the savings-and-loan crisis suggest lawyers and managers breached duties by "artificial[ly] prolong[ing]" the lives of their corporations. See, e.g., Schacht v. Brown, 711 F.2d 1343, 1348 (7th Cir. 1983); In re Phar-Mor, Inc. Scc. Litig., 900 F. Supp. 784, 787 (W.D. Pa. 1995). None of these cases give any meaning to the concept of corporate intercsts independent of the conclusions they invoke them to justify. 
dissolution (notably, shareholders will benefit when there are significant assets but no going concern value). It makes as much sense to speak of a corporation benefiting from dissolution as it does to speak of a corporation benefiting from a tax refund. In both cases, the corporation stands as a proxy for interests of its human constituents. ${ }^{89}$

The second point is that, when we reify or personify the corporation, it is usually to segregate a particular subclass of the interests associated with it. These are the interests associated with ownership. In the business corporation, ownership claims are associated with the provision of capital, but there may be other bases through which shareholders acquire ownership (and in some other organizational forms, such as charitable nonprofits or cooperatives, capital supply is usually not a basis for ownership claims). The critical distinction - the one that motivates organizational personification-is between residual claims and ordinary contract claims. Ownership claims are residual. Residual claims and ordinary contract claims can be either for financial or control rights. In the business corporation, residual financial claims tend to go with (but do not always coincide with) residual control claims.

Residual claims tend to be less specified than ordinary contract claims. Ordinary contract is more likely to specify a fixed return, a defined performance, or a set of particular protective covenants. But the critical distinction is that residual claims are secondary or "junior" to contract claims. This does not mean that they are less important. It means that scope can be defined only after ordinary contract duties have been delineated. The residual rights apply to what is left over (control or economic surplus) after ordinary contract claims have been given their due.

The personified corporation is a proxy for these residual claims. We tend to speak of these residual claims as "fiduciary" and to contrast them to "contract" claims. Residual claims by their nature are harder to specify. Moreover, residual claims typically entail both greater risk and greater possibility of exceptional gain, and both possibilities lead those who hold such claims to look for greater trust in their collaborators than the law provides for arm's length contract relations. Thus, fiduciary or residual-claim duties often require more initiative in pursuing shared ends, more forbearance in pursuing selfish ends, and more candor than ordinary contract duties.

Nevertheless, the contrast is to "ordinary contract," not to contract tout court, because the duties associated with residual claims and corporate personality are to an important extent contractual. They depend

89. To say that corporate "interests" are a function of constituent interests does not necessarily imply either (1) that the only relevant constituent interests are shareholder interests or (2) that all constitucnt interests are monetizable. In the Time-Warner takeover case, for cxample, the court gave weight to a public and employee interest in Time-Warner's "corporate culture" of "journalistic integrity." Paramount Communications v. Time, Inc., 571 A.2d 1140 (Del. 1989). The argument here does not depend on any position on such issues. 
in substantial part on agreement, and they are discerned through the techniques of contractual interpretation..$^{90}$

\section{The Importance of Distributive Norms}

The residual-claim contract that constitutes the corporation as an entity is a Framework of Dealing. It consists of both procedural and substantive norms. It includes specific negotiated terms, implied agreed terms, and background default and mandatory terms supplied by law. These terms appear in a variety of sources, including articles, bylaws, contracts, statutes, and cases.

One further distinction that can be made among the norms of the Framework of Dealing is between allocative and distributive norms. Allocative norms concern the pursuit of aggregate benefits. The ultimate allocative norm is "maximize constituent welfare," but there are a variety of subnorms that may specify the meaning of such welfare (for example, short term or long term) and the means that can be used to attain it (for example, levels of risk, lines of business). The other type of norm is distributive. Distributive norms specify how control and financial benefits in the firm are divided among constituents.

It is easy to think of the allocative interests of constituents as converging on a continuing basis. As long as distributive norms give each constituent a fraction of the corporation's net assets and income, all share an interest in maximizing these assets and income. Distributive norms, however, may converge only ex ante. At the time the constituents join together (or a later-arriving constituent joins an established organization) the distributive norms make collaboration possible. As the collaboration proceeds, a constituent will have an interest in getting a larger share than she bargained for, but like ordinary contracts, the organizational Framework of Dealing is designed both to resolve conflict and to preserve the integrity of the general organizational structure by holding constituents to their distributive commitments.

Unfortunately, corporate doctrine tends to speak of allocative norms as defining the "interests of the entity" and to think of distributive rorms as a matter of the "personal" or "individual" interests of the constituents. ${ }^{91}$ For

90. The term "nexus of contracts" favored by some economically minded scholars of the corporation is not helpful in describing the Icgal significance of corporate personality. Not only is "nexus" a term without any conventional legal meaning, but it blurs the critical distinction between the residual-claim contract implied by corporate personality and other, more conventional contractual relations in which the enterprise is involved.

91. There is a parallel tendency to think of fiduciary norms as duties to maximize a unitary interest, as opposed to duties to make a fair division among interests. The duty to maximize may be the most distinctive feature of fiduciary norms, but when there is more than one beneficiary, a plausible conception of fiduciary duty has to involve both types of norms. (Even with single beneficiaries, the trustee's rights to compensation and other benefits have to be measured in terms of fairness.) See 
example, in the shareholder suit context, it is customary to say that claims belong to the corporation (that is, are derivative) if they concern injury "to the whole body of [the entity's] stock or property without any severance or distribution among shareholders." By contrast, claims are direct "where the shareholder suffered an injury separate and distinct from that suffered by other shareholders." 92

This mode of thought has powerful consequences when its narrow conception of corporate interests is used to define the scope of the lawyer's responsibility to an organizational client. We see this in the Restatement. ${ }^{93}$ Its provision on organizational representation substantially tracks Model Rule 1.13, but adds some examples. According to one of them, where a corporate manager asks the lawyer to draft a document making a gift of a corporation-owned new car to a social friend, the request is against the interests of the corporation and must be refused. On the other hand, where a controlling shareholder attempts to unlawfully dilute the value of minority shares, the injury is considered individual, and the lawyer is to remain passive. ${ }^{94}$

Presumably, the difference rests on the form of the actions. The gift is formally a transaction between the corporation and a third party; the dilution occurs through internal corporate action. But there is no reason of policy or principle to classify the two situations differently for the purposes of professional responsibility. From the constituents' points of view, the economic effect of the two types of action is the same-the value of her stake in the enterprise has been diminished. It is no consolation to her that in one case the wrongful act takes an intracorporate form. Nor is there any reason to think that one category of injury is more or less frequent, severe, or hard to detect than the other. Moreover, the distinction is quite manipulable. With large stakes, constituents with extensive control will often be able to find some intracorporate process to achieve most improper goals. ${ }^{95}$

Virtually all intracorporate disputes are distributive. This is literally true in the sense that the distribution of control is always at issue in a dispute among corporate constituents. It is virtually true in the sense that nearly all tenacious disputes involve economic conflicts of interest.

Robert Clark's helpful discussion distinguishing between fiduciary duties to be "loyal" on the one hand and "fair" on the other. Robert Charles Clark, Corporate Law 635-36 (1986).

92. 12B William Meade Fletcher, Cyclopedia of the Law of Private Corporations $\S 5911$ (rev. perm. ed. 1984).

93. RESTATEMENT OF THE LAW Governing LaWyers, supra note 2,

94. Id. at $\$ 96(1) \mathrm{cmt}$. e, illus. $1 \&$ 2, at v. 2, 183-84.

95. For example, instead of selling corporate assets to his friends at bargain prices (thereby triggering corporate injury and counsel duty), a corporate manager can cause the corporation to be merged with a controlled entity under tcrms in which the minority shareholders receive less than fair value for its shares (thereby triggering merely individual injury and excusing counsel of responsibility). In theory, this could be done for particular assets by transferring them to a subsidiary, distributing the subsidiary stock to the parent shareholders, and then merging the subsidiary with a controlled entity. 
Corporate disagreements rarely become disputes and almost never reach the courts when they are simply matters of disinterested differences of opinion over how to maximize aggregate benefits to residual claimants.

From the perspective of both client and lawyer, the organization can only be regarded as a unity if it appears to reconcile the interests of its participants. No one would become a corporate constituent if he did not envision arrangements that promised both an aggregate return to the group and a fair share of it for him. Professional responsibility doctrine could not permit simultaneous representation of the constituents if there were not some set of norms under which collaboration would be mutually beneficial. From both perspectives, the distinction between allocative and distributive norms is unimportant. Both are fundamental to the Framework of Dealing that constitutes the organization.

It is dangerous to think of this framework as a contract because the word connotes arm's length relations and literalistic interpretations that are inappropriate here. But the techniques through which the framework of dealing is elaborated and applied are contractual. A broad range of judicial opinions illustrate these techniques, but the illustrations are often misleading because the interests involved are mischaracterized.

Consider, for example, two well-known cascs about dividends. Sinclair Oil Corp. v. Levien involved the Venezuelan subsidiary of a multinational oil company. ${ }^{96}$ The parent, Sinclair, owned $97 \%$ of the subsidiary, Sinven's, shares; public shareholders held the remaining 3\%. The parent-controlled board stopped new investments in Venezuela and began paying out the large revenues from past investments there as dividends. Minority shareholders claimed that Sinclair and the board breached fiduciary duties by failing to reinvest. They noted that Sinclair had made large investments through other subsidiaries in Alaska, Canada, and Paraguay that could have been made through Sinven. The Delaware Chancellor had characterized the board's actions as interested-director transactions and had put the burden on the defendants to show that they were fair. The appellate court disagreed, holding that so long as all shareholders received dividends pro rata, there was no conflict of interest, and hence the decisions were protected as business judgments.

Smith v. Atlantic Properties involved a close corporation in which three of four shareholder-directors charged the fourth with breach of fiduciary duty for refusing to permit the payment of a dividend.$^{97}$ Under the Artieles, board action could be taken only with the agreement of all four directors. For several years, they deadlocked, three to one, over whether to reinvest earnings, as the defendant desired, or pay them out, as the plaintiffs desired. Unfortunately, the deadlock prevented the firm from taking 
either course and caused it to incur tax penalties for unnecessary accumulation of income. The court held that the defendant had breached a fiduciary duty by deadlocking the board and found it liable for these penalties. The court seemed influenced by the suggestion that the defendant, who was wealthier than the plaintiffs, was motivated by a desire to avoid personal income taxes he would have had to pay on dividends.

In both cases, the courts speak as if the controversy among shareholders is to be resolved in terms of some corporate interest that transcends constituent interests. The Delaware court finds that the parent corporation in Sinclair had no conflict of interest in the dividend decision; ${ }^{98}$ the Massachusetts court holds that the Smith defendant was wrong to consider his conflicting individual interest. ${ }^{99}$ But in both cases, if we put distributive norms aside, there is no corporate interest independent of the constituent interests. A rational dividend deeision should take account of the opportunity costs and tax positions of the constituents. In each of the two cases, we have separate groups of shareholders with differing opportunity costs or tax positions, and hence, different interests. The Sinclair court was wrong to deny that Sinclair had a conflict of interest. Since its opportunities were broader than those of the public shareholders, its interests were different. Similarly, the Smith court was wrong to suggest that it was per se illegitimate for the defendant to consider his personal tax position. The decision had to be based on at least some constituents' personal interests because there were no other relevant interests. A decision for the majority was a decision that their interests were entitled to precedence.

When constituent interests conflict as they do in these cases, we have to look to distributive norms to resolve the conflict. When the norms are not explicit, we can use contractual techniques of implicit interpretation. While neither case makes an effort to articulate the relevant distributive norm, each indicates some relevant evidence.

In Sinclair, the salient fact is the unusual shareholder structure. Why would the multinational sell only a $3 \%$ interest in the Venezuelan subsidiary? This move could not have yielded significant capital. The most likely explanation is that the offering facilitated some local shareholding for regulatory or political purposes. If that was the purpose, it would be relevant only to Venezuelan investments. This suggests that the public shareholders had no reasonable expectation that Sinven would be a vehicle for them to participate in non-Venezuelan investments.

In Smith, the salient faet is the unanimity-voting rule, agreed to at the insistence of the defendant and apparently with the knowledge that he was more affluent than the others. The question then is whether the tax contingency that prompted the defendant's vetoes was within the range of issues 
for which the parties should have expected the veto power to be available. If, as the facts recited by the court suggest, everyone should have understood that this was one of the defendant's reasons for bargaining for the veto, then they should not now be permitted to object.

From a distributive point of view, the Sinclair decision for the defendants seems right; the Smith decision for the plaintiffs seems wrong. The key point is that each case should be decided, not through a search for transcendent corporate interests, but by recognizing that the relevant stakeholder interests conflict and looking for a distributive norm that indicates which ones should prevail.

The Delaware and Massachusetts courts' failure to acknowledge the distributive nature of the conflicts reflects the conventional tendency to see fiduciary duties as not embracing distributive issues. They were right to assume that the norms that constitute the entities involved in the cases should speak to issues as basic as the ones raised. But corporate norms can only address such issues plausibly if they include distributive as well as allocative norms.

One of the Restatement hypotheticals offer a further example of the consequences of personifying the corporation in a way that treats distributive norms as external. ${ }^{100} \mathrm{~A}$ lawyer is representing a close corporation with a dominant shareholder. The dominant shareholder has asked the board, consisting entirely of his designees, to adopt a plan to repurchase shares under terms that a minority shareholder protests will substantially reduce the value of his stock. The hypothetical tells us that under state law a dominant shareholder owes a fiduciary duty to a minority not to cause directors to take action that substantially reduces the value of the latter's stock. It concludes that the lawyer is "not obliged to advise against or otherwise seek to prevent action that is consistent with the board's duty to the client." 101

While the text is written with the circumlocution that is a hallmark of the bar's treatment of such issues, it seems to assume that a board action induced by a dominant shareholder in breach of his duties to a minority could somehow be "consistent with the board's duty to" the corporation. ${ }^{102}$ The language fails to clearly state whether it assumes this will always, or only sometimes, be the case. It offers no authority and suggests no analysis as to how one might determine whether and when it might be the case. It seems to simply rest on the conventional assumption that a violation of distributive norms is not an injury to the corporation.

The implausibility of this premise is magnified in a further hypothetical. We are now asked to assume that the minority is likely, not only to

100. Restatement of THE LAW Governing LAWYERs, supra note $2, \S 96 \mathrm{cmt}$. g, illus. 2.

101. Id.

102. Id. 
protest the repurchase plan, but to challenge it successfully in a "suit against the Client, and that Client will likely incur substantial expense as a result." ${ }^{103}$ In these circumstances, the drafters assert, the lawyer "owes a duty to protect the Client." 104 The extent of the duty is unclear, since the only action mentioned is "advising the Client's board against adopting the plan."105

Many will find difficult to square with any recognizable concept of ethics the negative implication that, if the minority never learns of the unlawful conduct and is thus unable to challenge it successfully, the lawyer's duty to oppose it does not arise. The Restatement seems to say that the lawyer must oppose the unlawful conduct only if it seems unlikely that the wrongdoers are going to get away with it. Although preposterous as ethics, this position follows from an understanding of corporate personality that excludes distributive norms. Note also the further bizarre implication that the potential injury to the corporation arises only from the possibility that it will bear litigation expenses. If the wrongdoer commits to reimburse such expenses in the event of discovery and loss, does that obviate the lawyer's duty?

Conventional doctrine, in a largely tacit and unreflective way, treats the corporation as a set of norms that promote a collaborative effort to maximize joint gains but invite a Hobbesian free-for-all with respect to how they are divided. In fact, distributive norms are just as fundamental and integral as allocative ones to the coherence and viability of the organization.

\section{The Irrelevance of the Direct-Derivative Distinction}

The strongest corporate law influence on professional responsibility is the practice of distinguishing entity from individual constituent interests that persists today largely in connection with derivative suits. A breach of duty to corporate interests is supposed to be litigated as a derivative suit while a breach of duty to constituent interests is supposed to be litigated as an individual suit or a class action. Some of the rhetoric employed in the course of elaborating this distinction suggests that distributive claimsthose that assert a "separate and distinct" shareholder injury-are direct. ${ }^{106}$

In fact, this doctrine is anachronistic and empty. The purpose of the exercise is ostensibly to determine the procedural incidents of a shareholder claim, but in fact classifying claims as direct or derivative is of no value for this purpose, and the practice has ceased to play a meaningful role in most contexts. Several jurisdictions have abandoned the practice

103. Id. $\S 96 \mathrm{cmt} . \mathrm{g}$, illus. 3 .

104. $I d$.

105. Id.

106. See supra text accompanying note 92 . 
explicitly in close-corporation cases ${ }^{107}$ Elsewhere the doctrine is so riven with incoherence and inconsistency that it cannot drive outcomes.

There is wide disagreement about how to classify many actions, such as those challenging "poison pills" and other defensive tactics. ${ }^{108}$ Even where there is agreement, the conclusions often seem inconsistent with the principle they are supposed to reflect. (A suit to compel a dividend or to enjoin an unauthorized act is usually considered direct, even though all shares are affected equally.) A plaintiff often can plead an action so as to trigger whichever characterization she prefers. (A challenge to a dilutive merger will sound derivative if financial dilution is emphasized; direct if voting dilution is emphasized.) The whole point of the exercise is to help determine such matters as whether the plaintiff will have to post security for the defendant's expenses, whether corporate management's judgment that the suit should not proceed will be given weight by the court, whether the recovery will go to the corporation or the individual plaintiffs, and whether a judgment will bind all shareholders. Traditionally, in a derivative suit, the plaintiff must post security, the board gets deference, recovery goes to the corporation, and all shareholders are bound. The opposite consequences follow from a characterization as direct. ${ }^{109}$ However, the class action device has made it possible to bind all shareholders in a direct suit in most situations where it is desirable to do so, and for years, the courts have been recognizing that the other consequences produced by the traditional doctrine often do not make sense. Thus, they have created exceptions. For example, even if a suit is derivative, the recommendation to dismiss by a severely conflicted board will not get much deference. ${ }^{110}$ And if wrongdoers are in control of the corporation, recovery, even if deemed derivative, may go to the plaintiffs. ${ }^{111}$ This process, by which the court determines the procedural incidents of the lawsuit by referring directly to the relevant values, will likely continue.

The distinction between allocative and distributive norms is useful in discussing the scope of constituents' discretion to bring suits over corporate policy. A purely allocative dispute involves no economic conflict of interest; it is just a disagreement over business policy. A presumption against judicial intervention in such cases makes sense. The businessjudgment rule expresses such a presumption as a matter of substantive law. A disinterested decision by management not to assert a potential corporate

107. Am. Law Inst., Principles of Corporate Governance $\S 7.01$ (d) (stating court has discretion to treat nominally dcrivative claims as direct in close corporations) \& Reporter's Note, para. 4 (citing cases) (2001).

108. Cox ET AL., supra note 77, at 405 n.39.

109. AM. LAW INST., supra notc $107, \S 7.01$ \& Reporter's Note; Cox ET AL., supra note 77, at 400-06 (1997).

110. E.g., Zapata v. Maldonado, 430 A.2d 779 (Del. 1981)

111. E.g., Atkinson v. Marquart, 541 P.2d 556 (Ariz. 1975). 
claim against a stranger to the corporation, for example, ought to carry a stronger presumption of nonreviewability than a decision with internal distributive consequences. If the derivative-direct distinction had been employed simply to limit judicial review of allocative disputes, it might serve some purpose. But it has not been. The courts have not reserved the derivative characterization for allocative disputes. As we have noted, most disputes that reach litigation are distributive, and the doctrine characterizes many of them as derivative.

If the direct-derivative distinction has very little connection to the procedural issues at stake in corporate litigation, it has nothing at all to do with most issues of corporate professional responsibility. The tendency to define the scope of the corporate lawyer's obligations in terms of the norms associated with derivative suits is fruitless and arbitrary.

\section{Doctrinal Applications}

Although the Framework of Dealing perspective is a departure from the dominant doctrinal tendencies on organizational representation, it does seem to be presupposed in a few specific doctrinal areas. These areas seem like anomalies under the dominant view. The Framework of Dealing perspective gives a better explanation of them than conventional doctrine can offer.

\section{Insider Trading}

As applied to lawyers, the insider-trading prohibition illustrates a duty to a corporate client that depends on substantive fiduciary notions, rather than on the factors emphasized by the Control Group and Authority Structure models. Neither officers nor the board, nor perhaps any corporate body, could authorize the trading prohibited by this norm. The norm also illustrates the inadequacy of the conception of corporate interest that professional responsibility has inherited from traditional corporate law.

The insider-trading prohibition is a mandatory term supplied by federal seeurities law, but it has been explicitly derived from and elaborated in terms of fiduciary duty. ${ }^{112}$ Yet, prior to the advent of the federal doctrine, state cases found liability in only some of the circumstances covered by the current prohibition. If the insider affirmatively misled, liability to the party with whom she traded might be supported by conventional misrepresentation doctrine. Where the trading caused some tangible loss to the corporation-for example, by causing premature disclosure of a business strategy-liability to the corporation might be based on this harm. But in the core situation where the insider simply trades anonymously without disclosing material information, the courts tended to reject liability. ${ }^{113}$ They

113. See, e.g., Goodwin v. Agassiz, 186 N.E. 659 (Mass. 1933). 
would say that the insider's duty was to the corporation, not to the shareholder she traded with, and that, since the only effect of the trade was to shift wealth around among the shareholders, there was no corporate harm.

The federal doctrine, which extended liability to the core case, gained broad public acceptance, and some state courts incorporated its principles into state doctrine. However, when economics came to the fore in business law scholarship in the 1970s, the core case once again seemed problematic, at least for academics. Law-and-economics scholars thought corporate law should be based on efficiency considerations, and they had difficulty finding any that supported the prohibition. Eventually, they came up with some. For example, the prohibition makes for more explicit, and hence more certain, forms of executive compensation. 1t eliminates the incentive for managers to increase firm volatility in order to maximize trading opportunities. ${ }^{114}$

These rationales are, however, quite speculative and do not seem to be the ones that most strongly motivate public support for the prohibition. The economists' preoccupations with efficiency parallels the tendency in traditional corporate doctrine to define distributive concerns as external to the corporation.

Yet, the reasons that most strongly motivate public support seem to be distributive. Information gained in corporate service is considered a collective asset in which constituents should share in proportion to their stakes. Moreover, it is generally regarded incompatible with fiduciary loyalty to profit secretly on information gained in a position of trust. This principle is a traditional one in the law of agency and of trusts. ${ }^{115}$ It seems to be equally grounded in lay opinion. On the Framework of Dealing perspective, these distributive convictions provide ample ground for interpreting the corporate residual-claim contract to include the prohibition. Thus, the insider trading approach is consistent with the contractual methodology of the Framework of Dealing approach, and it confirms the premise that a corporation should be understood to have interests in the integrity of its distributive structure.

\section{Derivative-Suit Defense}

We have seen that a derivative suit alleging wrongdoing by incumbent management can present a conflict that precludes joint representation of management and the corporation. ${ }^{116}$ Joint representation has been deemed appropriate when the claim is potentially weak, especially if likely to be

114. See ClaRK, supra note 91, at 265-77.

115. Restatement of Agency, supra note 39, $§ 395$ (1958); Restatement (SeCOND) OF Trusts $\S 170, \mathrm{cmt}$. d (1959).

116. See supra notes 61-63. 
dismissed in an early proceeding. ${ }^{117}$ Where the claim is substantial, a prominent view holds that corporate counsel should represent only the organization, and in doing so, should remain neutral or "passive." 118 In other words, the lawyer first makes a preliminary assessment of the merits; if she is unable to determine them, she must remain neutral.

The practical importance of these doctrines is unclear. Whoever represents management will have full access to corporate information and will very likely be paid out of the corporate treasury or by its insurer. Corporate counsel will still have been chosen by management, and within limits will continue to be instructed by it. (Corporate counsel may, for example, orchestrate the establishment of an ostensibly "independent" committee of directors or advisors to assess the merits of the claims on the corporation's behalf.)

Nevertheless, the doctrine is interesting because it seems to reflect the Framework of Dealing conception of representation. It departs from the Control Group view in refusing to identify corporate interests with management interests. In addition, it departs from the Authority Structure view both in acknowledging that authority is ambiguous in this situation and in suggesting that professional responsibility decisions can require consideration of the substantive merits of an internal dispute. In deciding that joint representation is appropriate in the case of frivolous claims, the lawyer is deciding that management's position is most consistent with the Framework of Dealing. Where the claim is nonfrivolous, neutrality is required because the absence of a determinate Framework makes it impossible to determine what client interests are. ${ }^{119}$

Federal court doctrine on attorney-client privilege in derivative suits reflects the Framework of Dealing perspective in a similar manner. The leading case of Garner $v$. Wolfinbarger holds that the privilege should not block discovery of management communications with corporate counsel where the plaintiff can show "good cause" for her inquiry. ${ }^{120}$ Among the factors that the court considers in deciding whether good cause exists is "the nature of the shareholder's claim and whether it is obviously

117. E.g., Hausman v. Buckley, 299 F.2d 696 (2d. Cir. 1962).

118. See Yablonski v. United Mine Workers, 448 F.2d 1175, 1181 (D.C. Cir. 1971); Geoffrey C. Hazard, Jr. et al., The Law and Ethics of Lawyering 730 (3d ed. 1991).

119. The doctrine departs from the basic logic of the Framework of Dealing approach in one respect-the consequences of assessing the merits are asymmetrical. If the claim is clearly without merit, corporate counscl can rcpresent management. However, there is no corresponding precept that if the claim clearly has merit, corporate counsel can align herself with the plaintiffs. At least, the weight of authority is against this precept. See Richardson v. Hamilton, 469 F.2d 1382 (3rd Cir. 1972), cert. denied, 411 U.S. 986 (1973); Doe v. A Corp. 330 F. Supp. 1352 (S.D.N.Y. 1971); Goldstein v. Lees, 120 Cal. Rptr. 253 (Cal. Ct. App. 1975). However, one case could be read to support it. See Jacuzzi v. Jacuzzi Bros., Inc., 32 Cal. Rptr. 188 (Cal. Ct. App. 1963).

120. 430 F.2d 1093 (5th Cir. 1970). 
colorable." 121 If the claim is patently weak, management's claim of privilege is likely to be upheld. If it is facially strong and the information sought seems important, then privilege is likely to be denied. Again, the organizational lawyer's duty in a situation of intraclient conflict depends in part on an assessment of the merits of the competing claims. Although the Garner doctrine has been called "an exception" to the attorney-client privilege, ${ }^{122}$ it makes more sense to think of it, not as limiting the privilege, but as determining who should decide on behalf of the corporation whether it should be invoked. Where the plaintiff asserts an apparently strong claim, she, rather than management, is permitted to speak for the organization on this point. This is in the spirit of the Framework of Dealing approach.

\section{Duties to Nonshareholder Constituents}

The Control Group and Authority Structure perspectives are not responsive to the interests of constituents who have neither actual control nor a role in the corporation's authority structure. Many people believe a board's fiduciary duties extend to a variety of shareholder constituencies, including employees, customers, suppliers, and the local communities in which they operate. ${ }^{123}$ These suggestions are controversial, though there is some support for thcm in state "other constituency" statutes. ${ }^{124}$ In addition, therc is significant judicial support for the notion that the board has fiduciary duties to creditors when the corporation is in the vicinity of insolvency. ${ }^{125}$

Those who deny that duties extend to nonshareholder constituencies will not be interested in pursuing the implications of these duties for corporate lawyers. Moreover, one might concede the validity of the board's duties and still suggest that they are too indeterminate to yield any conclusions for lawyer responsibility. However, some of the cases recognizing possible liability for lawyers and accountants involved in the savings-and-loan failures of the 1980 s might be read to suggest the contrary. Opinions in some of these cases suggested that lawyers and accountants breached their duties to the corporation by failing to take actions to protect creditors from the financial improprieties of managers. ${ }^{126}$ The cases were

121. Id. at 1104. Cases are divided as to whether the Garner prineiple applies in class actions. Compare Weil v. Inv./Indicators, Research \& Mgmt., 647 F.2d 18 (9th Cir. 1981) (no), with Ward v. Succession of Freeman, 854 F.2d 780 (5th Cir. 1988) (yes).

122. Dickerson v. Superior Court, 185 Cal. Rptr. 97, 100 (Cal. Ct. App. 1982).

123. See sources citcd in supra note 81 .

124. E.g., OHIo REv. CODE ANN. § 1701.59(E) (2002) (authorizing board to consider interests of various nonshareholder constituencics in making decisions about control transactions).

125. Laura Lin, Shift of Fiduciary Duty upon Corporate Insolvency: Proper Scope of Directors Duty to Creditors, 46 VAND. L. Rev. 1485 (1993).

126. F.D.1.C. v. O'Melveny \& Mycrs, 969 F.2d 744 (9th Cir. 1992), rev'd, 512 U.S. 79 (1994); Schacht v. Brown, 711 F.2d 1343 (7th Cir. 1983); F.D.l.C. v. Nathan, 804 F. Supp. 888 (S.D. Tex. 1992); In re American Contincntal Corp., 794 F. Supp. 1424 (D. Ariz. 1992). For a discussion of thesc 
brought by receivers and bankruptcy trustees. They do not explicitly suggest a duty for lawyers to make disclosures to creditors, but the conduct on which the claims were based seems to have harmed creditors, not shareholders. ${ }^{127}$

For example, F.D.I.C. v. O'Melveny \& Myers involved the fraud in sale of real estate interests by the senior managers and sole owners of the corporation. ${ }^{128}$ After reimbursing the purchasers, the receiver sued the lawyers, alleging that they had breached a duty to the corporation by failing to discover and take action with respect to the fraud. The lawyers argued that the corporation had "no identity separate from that" of the two ownermanagers. ${ }^{129}$ The court replied that the bank had a "corporate identity distinct from that of its wrongdoing officers" and ruled for the receiver. ${ }^{130}$

In F.D.I.C. v. Nathan, senior managers who owned $90 \%$ of the common stock engaged in fraudulent transactions. ${ }^{131}$ Again, the receiver sued the lawyers for breach of duty to their client in assisting and "fail[ing] to warn any nonculpable party" of the misconduct. ${ }^{132}$ The lawyers argued that they could not be liable for conduct "ratified by the shareholders of at least ninety percent of Continental's shareholders." 133 The court rejected the argument.

Some cases hold that the corporation, and hence the bankruptcy trustee, is "estopped" from bringing suit where the wrongdoing was the responsibility of senior management. ${ }^{134}$ But the cases we are considering hold otherwise. To hold that suit is possible is to invoke something like the Framework of Dealing conception of the corporation. These cases imply that the corporation has a set of interests for which fiduciaries are responsible that exist independent of its control and authority structure. The conduct in question is attributable to the control group and it is authorized in a procedural sense. In cases like O'Melveny and Nathan, the "highest authority that can act on behalf of the corporation," to use the language of Model Rule 1.13, is responsible for the wrongful acts. ${ }^{135}$ If lawyers are nevertheless liable to the corporation for assisting such conduct, their duties to their organizational client must involve more than its authority structure.

and related cases, see George C. Harris, Taking the Entity Seriously: Lawyer Liability for Failure to Prevent Harm to Organizational Clients Through the Disclosure of Constituent Wrongdoing, 11 Geo. J. LeGal Ethics 597 (1998).

127. See Harris, supra note 126 , at 627.

128. O'Melveny, $969 \mathrm{~F} .2 \mathrm{~d}$ at 744 .

129. Id. at 748 .

130. Id. at 751 .

131. Nathan, 804 F. Supp. at 888.

132. Id. at 896 .

133. Id.

134. See Harris, supra note 126, at 627-32 and cases cited.

135. Model RuLES, supra note 1, at R. 1.13. 
One feature of the cases that has troubled the courts is that, even where the illegal conduct was not undertaken directly by shareholders, it was usually undertaken by managers attempting to benefit shareholders, and it would have benefited shareholders if it had been successful. To be sure, in hindsight things worked out badly for shareholders, but management efforts to advance shareholder interests are usually assessed ex ante and given much deference. For this reason, the Seventh Circuit holds that professional liability for breach of duty to the corporation for internally authorized conduct requires a showing that the managers were acting to further their own personal interests at the expense of shareholders. ${ }^{136}$

The Seventh Circuit's holding makes sense if the only constituent interests that constitute the corporation's identity as a client are shareholder interests. However, growing authority suggests that the effect that creditors be considered constitutive as the corporation approaches insolvency. ${ }^{137}$ The reasoning is consistent with the Framework of Dealing perspective. In that view, the corporation is an implicit contractual structure that organizes the interests of residual claimants. The creditors have a kind of contingent residual claim that may be perfected in bankruptcy. But until then, many actions potentially beneficial to shareholders would subject these contingent interests to severe risk. The closer the firm gets to insolvency, the greater the weight creditors claims should be entitled relative to shareholder claims. Thus, the savings-and-loan cases finding professional liability make sense on the premise that creditors are among the relevant constituents in this situation.

\section{VI \\ The Entrty Approach Summarized and Compared}

\section{A. An Integrated Entity Approach}

It is possible, but not defensible, to apply either the Control Group or the Authority Structure models alone as a comprehensive guide to the responsibilities of the organizational lawyer. The Framework of Dealing approach, however, presupposes both of them.

The Control Group view contributes a presumption that senior management and the board represent the organization. It is based in part on management's authority to make ordinary business decisions and the board's authority to make policy decisions. (To this extent, it overlaps the authority-structure approach.) It is also based on the fact that across a broad range of decisions, management's incentives arc well aligned with those of other constituents, and management is likely to be better informed than any other decisionmaker. This range consists mainly of allocative

136. See Cenco Inc. v. Seidman \& Seidman, 686 F.2d 449, 454-56 (7th Cir. 1982)

137. See Lin, supra note 125. 
decisions-those that affect shareholders in equal proportion to their distributive shares. Finally, the presumption is based on the psychological tendency of lawyers to identify the organization with the agents with whom they work, and the fact that this tendency facilitates valuable communication and collaboration.

The Control Group prcsumption should not be a strong one, however. It clearly should not survive indications that management is violating authority or fiduciary norms. Moreover, it should not apply in situations involving distributive issues where management might have a conflict of interest. This includes situations of actual constituent conflict as well as situations of potential constituent conflict, in particular, situations in which it seems likely that there would be conflict if material information not available to constituents were provided to them.

Where the Control Group presumption is not dispositive, attention should shift to procedural norms, the focus of the Authority Structure perspective. The lawyer asks to which agents the corporate legal structure confers ultimate responsibility over the issue. Where the lawyer has substantial doubts that a particular course of corporate conduct is in the interest of the organization, and the conduct has not received informed consideration by the agents with ultimate authority, the lawyer ought not to assume that those engaged in the conduct speak for the corporation. In this instance, the lawyer should facilitate review by the agents with authority. In the most common case, this would involve urging management to seek board authority. In a more extreme case, it would involve bypassing management and going to the board. A still more extreme course would be to make direct contact with shareholder constituencies and, at the limit, with public authorities.

Where authority is ambiguous or disputed, the authority-structure perspective implies that the lawyer ought to try to facilitate clarification of it. This would most commonly mean assuring that all the relevant constituents have material information. It would be consistent with this principle, for example, for counsel representing the corporation in a derivative suit to oversee the corporation's response to discovery rcquests with a view toward insuring the availability of material information. (Whether it is realistic to expect counsel to do this in a manner independent of incumbent management is another question.)

Somc cases require that analysis proceed beyond authority considerations. Although perhaps not often, it will sometimes happen that the lawyer can say confidently that the decision of the highest authority violates an important duty. Clcar violations will most likely occur when the duty protects interests that are not represented in the authority structure-for example, minority shareholders or creditors. In such circumstances, the lawyer has to make a substantive judgment about the corporation's interests and 
responsibilities. Disclosure to the affected constituent or a public authority might be the most plausible remedy.

With respect to conflicts, in intracorporate disputes where the lawyer cannot confidently make a judgment on the merits, the Framework of Dealing approach implies that neutrality is appropriate. On the other hand, in situations where the lawyer can make such a decision, she probably should be authorized to take sides with the meritorious claim, whether management or dissident. Current doctrine already provides this option in derivative suits with frivolous plaintiff's claims. It may be that an apparent lack of merit that does not rise (descend) to frivolousness should be sufficient. In any event, the doctrine should be symmetrical so that lawyers can ally with dissidents when their claims are strong. To be sure, it may be hard to police the reasonableness and good faith of lawyers' judgments of merit, but there is no reason to think that lawyers are more likely to be wrong when they side with dissidents than when they stick with management.

As for attorney-client privilege, the current Garner rule ${ }^{138}$ seems well adapted to the Framework of Dealing perspective. It defines the scope of confidentiality in terms of an assessment of organizational interests of exactly the sort that this perspective recommends.

Finally, where the lawyer has dealings regarding corporate matters outside the Authority Structure, the Framework of Dealing perspective prescribes duties of disclosure and fair dealing to constituents. These duties are consistent with specific prescriptions of current doctrine, for example, the insider-trading prohibitions of the securities laws, but the Framework of Dealing view provides a better explanation of these prescriptions than do the alternative models of organizational representation.

\section{B. Joint vs. Entity Representation}

The Framework of Dealing approach thus converges with joint representation more often than conventional discourse assumes. In the Founder Freeze-Out hypothetical, the two approaches suggest disclosure of the accountant's information, and both are likely to lead the lawyer to disqualify herself in the dispute between Founder and the Investor-dominated board.

Nevertheless, there are important differences in both their premises and their operating effect. The joint-representation perspective requires disclosure because the representation entails a commitment to provide material information to each constituent. The Framework of Dealing perspective, however, requires disclosure because it is needed to trigger the decision-making processes to determine the entity's interests. 
The joint-representation approach requires neutrality because the lawyer cannot represent a client in a matter adverse to another client, and even if the lawyer were allowed to withdraw from representing Founder, she would be forbidden to represent a client against a former client in a matter substantially related to the former representation. By contrast, the Framework of Dealing perspective requires neutrality because, if the lawyer cannot determine the merits of the claim, she cannot determine what the client's interests are. For the purposes of this dispute, there is simply no client to represent.

In the joint-reprcsentation approach, interests are largely a function of the individual desires and expectations of constituents. However much they converge at the outset of the relation, they may diverge in the course of it. In the Framework of Dealing perspective, the framcwork formulates the common expectations of the constitucnts in a relatively objective and stable form that can be attributed to the organization.

The lawyer's disclosure responsibilities to constituents will be substantially limited by the framework. A decision made by disinterested officers acting within their authority-a classic business judgment-normally will not raise disclosure issues within the framework of dealing.

Moreover, in the Framework of Dealing approach, there sometimes will be collective interests defined by the framework that militate against disclosure. In a public corporation, if disclosure would necessarily become public and likely entail adverse consequences for the corporation, those consequences should be weighed. It is doubtful that such concerns could ever justify acquiescence to clear wrongdoing, but they might warrant a higher threshold of certainty and materiality for disclosure in such situations.

For issues of attorney-client privilege, the Garner approach mandates just this kind of balancing inquiry, but since the matter is in court, it can be performed by the judge. Garner presupposes an entity. No issue of attorney-client privilege arises as between joint clients.

The Framework of Dealing will also limit client identity for conflicts purposes. Consider first conflicts among constituents. If the representation is joint, any substantial conflict will require neutrality from the lawyer. On the other hand, if the lawyer represents an entity, she need not withdraw if she can determine that the action in question is consistent with the authority and substantive norms of the Framework of Dealing.

With respect to conflicts between constituents and outsiders, whether representation is joint or organizational may affect the lawyer's ability to represent outsiders. Model Rule 1.7 on concurrent conflict prcvents representation of any client in a matter adverse to any other client, without both clients' consent. ${ }^{139}$ In a joint representation, this would preclude 
representing anyone with a claim adverse to any of the enterprise participants, even if the claim was unrelated to the business. In the Framework of Dealing approach, the lawyer represents constituents only collectively and with regard to the affairs of the business. Thus, an adverse claim against a constituent unrelated to the business would not be precluded.

The rules on successive conflicts will usually bar representation of any joint client against another over a matter relating to the enterprise. The result will be the same under the Framework of Dealing approach if the lawyer is unable to determine with confidence the merits of the dispute. There may, however, be situations where the lawyer can determine the merits with confidence, and there the framework of dealing supports the lawyer in siding with the meritorious claim. This constituent can plausibly claim to be speaking for the enterprise.

The choice between the two characterizations should make less difference than current discourse supposes in the scope of the lawyer's duty to offer advice. There is a tendency to assume that the lawyer in a joint representation will necessarily advise the constituents on individual as well as collective interests, while the organizational lawyer will have duties only with respect to the latter. For cxample, in Security Bank v. Klicker, the plaintiff was a member of a partnership in which all partners were asked to personally guarantee a partnership debt. ${ }^{140}$ When he got stuck with the liability because the others were judgment proof, he complained that the partncrship lawyer had not adequately advised him of the risks. The court dismissed the suit on the familiar ground that the partnership lawyer did not represent the partners individually.

However, the decision should not turn on this distinction. Klicker reflects the tendency to assume, from the organizational perspective, that the organization's interests are in maximizing its aggregate resources, while the constituent's interest in fair treatment is a purely individual one. I criticized this premise above with respect to cases involving internal corporate action. ${ }^{141}$ This case is slightly different in that it is not strictly internal. In effect, it involves a renegotiation of the Framework of Dealing, rather than a move within it. The existing framework will not dictate a particular outcome to the negotiation. On the other hand, thcre are general norms of fair dealing, including disclosure of material information that could plausibly be considered part of the framework. These norms might well include some consideration of particular intercsts of a constituent. We saw, for example, in considering dividend decisions that corporate decision making sometimes requires consideration of individual interests, such as tax constraints. The fiduciary duties imposed by substantive partnership law and the Wilkes 
cases $^{142}$ involving small corporation constituents are incorporated into the framework for the purposes of constituent dealings inter se. And the insider-trading prohibition illustrates that such norms can play a role even in large businesses.

There are limits on the knowledge that an organization's lawyer can be expected to have about individual constituent's interests or the degree of attention she can be expected to pay to them. In some situations, an organization's lawyer can, at most, be expected to suggest that the constituent retain separate representation. ${ }^{143}$ The more idiosyncratic the interests, and the more numerous the constituents, the stricter the limits. But some such limits would also apply in joint representation. Joint representation does not mean that the lawyer is responsible for every personal interest of each constituent. Professional responsibility norms authorize limitation of the scope of the representation, ${ }^{144}$ and joint representation of constituents in connection with a business venture will usually expressly or impliedly be limited to matters related to that venture. In Klicker, the interests surrounding a personal guarantee of business debts were related to the business, so the lawyer representing the constituents jointly should have some responsibility to warn the guarantor about the specific risks to her. ${ }^{145}$ Such a duty should not be precluded merely because the relation is characterized as organizational.

Where the distinction between joint representation and organizational representation does matter, two considerations bear on the choice of perspective. First, joint representation is most appropriate in situations with small numbers of constituents and informal dealings among them and with the lawyer. Second, the Framework of Dealing approach requires that there be some minimal degree of structure to the constituents' dealings and plans. The structure need not be explicit, and much of it can be supplied by default and mandatory terms, but the many informal relationships will lack sufficient structure to be treated as frameworks of dealing.

The Founder Freeze-Out scenario is a close case. The number of corporate constituents is small. I have been discussing the case as if there were only two constituents, although one of them is an organization, a limited partnership. Most start-up businesses with venture financing would have considerably more than two constituents, but not so many as to make joint representation impracticable. What weighs more heavily against this approach is the degree of formality. Start-up businesses are noted for flexible structure and collaborative style, but they are extensively negotiated and

142. See supra note 18 and accompanying text

143. This is an obligation the lawyer would sometimes owe even to a stranger. See MODEL RULES, supra note $1, \mathrm{R} .4 .3$, cmt. (noting that the lawyer has duty to clarify role to "unrepresented person" and may advise to obtain counsel).

144. See id. at R. 1.2(c).

145. Klicker, 418 N.W.2d at 27. 
elaborately documented. The participants arc typically sophisticated about legal and business issues. In the current state of doctrine, there is some pressure to adopt the joint-representation view because that would generate the best chance of establishing a disclosure duty to Founder. But we have seen that the most plausible version of the entity perspective supports a disclosure duty in this situation just as strongly.

\section{The Limited Potential of Client Prescription}

Model Rule 1.13 states that among the factors to be considered in determining duties to an organization are the organization's own policies concerning legal representation. ${ }^{146}$ The American Trial Lawyers' Association urges that corporate clients instruct their counsel specifically on how to act in the face of internal conflicts. ${ }^{147}$ No doubt it would be helpful for clients to consider such matters and try to formulate guidelines. $1 \mathrm{t}$ seems unlikely, howcver, that such efforts will obviate the need for judicially prescribed and enforced professional responsibility doctrine on these matters.

Organizational clients have not shown much inclination to address these issues through explicit policy, despite the fact that most have some awareness of the problems. Even if they were to do so, their efforts would be subject to two sorts of limitations.

First, as a matter of professional responsibility, clients cannot waive their rights to adequate representation. ${ }^{148}$ Moreover, any client agreement regarding representation is likely to be deemed invalid or inapplicable with respect to unanticipated future contingencies. ${ }^{149}$ Thus, even where specific organizational policies are in place, lawyers have a continuing obligation to consider the best interests of the organization in situations of internal conflict.

Second, as a matter of corporate law, any policies adopted by management that were inconsistent with their fiduciary duties would be invalid..$^{150}$ Policies that instruct lawyers not to disclose material information to the board or other constituents, who might otherwise be entitled to it, or to remain passive in the face of serious wrongdoing toward constituents, might well be deemed incompatible with fiduciary duty.

146. See Model Rules, supra note 1, at R. 1.13(b).

147. Am. Trial Lawyers' Ass'n, American Lawyers' Code of Conduct 2.5, in Thomas MorGAN \& Ronald Rotunda, 2002 Selected Standards of Professional Responsibility 419, 431.

148. See Model Rules, supra note 1, at R. 1.2, cmt. 5 (client may not be asked to waive right to competent representation).

149. See Westinghouse Elec. Corp. v. Gulf Oil Corp., 588 F.2d 221 (7th Cir. 1978); In re Boone, 83 F. 944,957 (N.D. Cal. 1897).

150. Even shareholder-adopted policies would have this problem. Although some states permit shareholders to waive managers' duty of care liability, for example, DeL. GEN. CoRP. L. $\S 102(b)(7)$ (2002), none permits waiver of duty of loyalty liability in the broad prospective sense that would be required to moot the issues with which we are concerned. 


\section{VII \\ NONCORPORATE ORGaNizations}

The argument so far suggests that the distinction between joint representation and a plausible conception of entity representation is not as great as many have assumed. It also suggests that the most important determinant of the choice of approach is not formality of organization, but whether these relationships have sufficient structure to constitute a Framework of Dealing. Without such a framework, workable entity treatment is not possible. With it, entity treatment will often be appropriate, though there may be cases involving small, informal collaboration, where joint representation is appropriate even with a Framework of Dealing.

Although never embraced explicitly and sometimes rejected implicitly, this view turns out to be surprisingly consistent with trends in the treatment by courts and commentators of professional responsibilities in a variety of organizational contexts.

\section{A. Partnerships}

In general, the courts have found it easier to apply the jointrepresentation perspective to support duties to constituents in the partnership than in the corporate context. ${ }^{151}$ This may reflect the greater legal informality of partnerships, the doctrine that partners owe each other fiduciary duties, and the adoption in some states of the "aggregate" (as opposed to the "entity") characterization of partnerships.

On the other hand, some cases purport to take an entity perspective, typically without elaboration, and a number of these dismiss claims by partners for lawyer participation in managerial expropriation, invoking the entity concept with the same glib circularity we have seen in closecorporation cases such as Skarbrevik. ${ }^{152}$

There is no reason to make any strong distinction between corporate and other business forms. The Framework of Dealing approach seems as readily applicable to partnerships as corporations, so long as they have the requisite degree of structure.

\section{B. Personal Trusts}

Several cases consider the extent to which a lawyer for a trustee is liable to the beneficiary for acquiescing to or assisting in injurious conduct.

151. See e.g., Pucci v. Santi, 711 F. Supp. 916 (N.D. 11l. 1989); Roberts v. Heim, 123 F.R.D. 614 (N.D. Cal. 1988); Johnson v. Superior Court, 45 Cal. Rptr. 2 d 312 (Cal. Ct. App. 1995); Arpali v. First MSP Corp., 628 N.E.2d 1335 (Ohio 1994); Griva v. Davison, 637 A.2d 830 (D.C. Ct. App. 1994); Wortham \& Van Liew v. Superior Court, 233 Cal. Rptr. 725 (Cal. Ct. App. 1987); see also ABA Formal Op. 91-361 (1991) (applying entity rhetoric but opining that material information "may not be withheld from the individual partners").

152. See, e.g., Richter v. Van Amberg, 97 F. Supp. 2 d 1255 (D.N.M. 2000); Quintel Corp. v. Citibank, 589 F. Supp. 1235 (S.D.N.Y. 1984); Rice v. Strunk, 670 N.E.2d 1280 (Ind. 1996). 
Liability for active tortious conduct for which a stranger could sue is fairly uncontroversial. The kind of liability for passivity and silence associated with fiduciaries has been more controversial. Some courts deny liability on the ground the trustee's lawyer owes no fiduciary duty to the beneficiary. However, the recent trend has been to hold that such lawyers do have some degree of fiduciary liability to beneficiaries. ${ }^{153}$

Geoffrcy Hazard has discussed the recent cases in terms of joint representation. ${ }^{154}$ Both trustee and bcneficiary can be considered clients. Conceptually, however, the joint-representation idea is an awkward fit because it implies client conscnt and control, whereas beneficiaries do not consent to their relations with trustees or lawyers, and they do not control their trustees or lawyers. Emphasizing this problem, Jeffrey Pennell and Robert Tuttle suggest that the lawyer should be conceived as representing a "fiduciary entity." 55 The fiduciary role has a structure of legal rules. Penncll and Tuttle suggest that the lawyer should be held accountable to this structure. They argue that the fact that the trustee and the beneficiary have conflicting interests or that different beneficiaries may have differing interests does not mean that there is no coherent client. The lawyer's duty is not to the individual interests of the participants, but to the convergent interests identified and incorporated in the trust relationships. ${ }^{156}$

Pennell and Tuttle's entity approach corresponds closely to the Framework of Dealing approach. The Authority Structure model is of relatively little use with a personal trust, since authority is usually unstructured and informal. The Control Group approach, which I suggested was of slight use with business corporations, is even less uscful with trusts, because a trustee's control is more tightly hemmed by fiduciary obligation than that of corporate directors and officers. But trusts do share with corporations a substantive legal identity constituted by mandatory, default, and privately adopted rules (with the difference that a trust beneficiary does not participate in the adoption process). The Framework of Dealing approach draws on this structure. ${ }^{157}$

153. The cases are surveyed in Tuttle, supra note 67. The best known of the cases finding duties to the beneficiary is Fickett v. Superior Court, 558 P.2d 988 (Ariz. 1976). See also RESTATEMENT OF THE LAW GOVERNING LAWYERS, supra note $2, \S 51(4)$ (stating that lawyer for trustee should take actions necessary to prevent trustee from breaching duty to beneficiary, with exceptions).

154. Geoffrey C. Hazard, Jr., Triangular Lawyer Relationships: An Exploratory Analysis, I Geo. J. Legal ETHICS 15 (1987).

155. Jeffrey Pennell, Representations Involving Fiduciary Entities: Who Is the Client?, 62 FORDHAM L. Rev. 1319 (1994); Tuttle, supra note 67, at 923.

156. "The attorney does not represent the beneficiaries' interest; she only represents their 'best interests' as that concept is objectified in the fiduciary entity." Tuttle, supra note 67 , at 923 ; see also Pennell, supra note 155 , at 19.

157. The approach of section 51(4) of the Restatement is much less satisfactory. See RESTATEMENT OF THE LAW GOVERNING LAWYERS, supra note 2, at \$ 51(4). It treats the beneficiary as a "nonclient" but gives the trustee's lawyer a duty to prevent wrongdoing by the trustee. This leads to 
Privilege and conflicts doctrines associated with the Framework of Dealing approach seems generally appropriate to trust situations. The Garner principles, which effectively give the court control over the entity's attorney-client privilege in disputes between entity and constituent, seem readily adaptable to trusts. ${ }^{158}$

For conflicts purposes, the entity perspective would treat representation of the trustee in his official capacity as not creating conflicts where the lawyer takes a position adverse to the trustee in his personal capacity. Tuttle expresses reservations about this, suggesting that the trustee is often more personally identified with his office than is the corporate officer. ${ }^{159}$ The trustee will often be a single individual operating informally. But this is not categorically true. The trustee could be a bank, and a closecorporation officer could be the only director and shareholder. Moreover, even in large corporations, wc have noted that lawyers have a tendency to identify the client with the agents with whom they interact.

\section{Charitable Organizations}

Charitable organizations usually take the legal forms of trusts or nonprofit corporations. The Framework of Dealing approach seems readily applicable here. These organizations usually have a determinate plan of goals and activities, and their managers function under a structure that limits authority more than business organizations do.

In contrast to business organizations, the most important beneficiaries of a charitable organization have little or no control rights. With this characteristic, they resemble beneficiaries of personal trusts, but since charitable beneficiaries are more diffuse, and their interests are more ambiguous, they typically have less incentive and ability to monitor the organization. The law responds to this limitation by giving supervisory responsibilities over charities to the state attorneys general, and if the organizations receive

one of those studied ambiguities so often encountered in the bar's doctrinc on organizational representation.

Since disclosure to or in the interests of nonclients is normally authorized only in very limited situations, we need to know what the relation of the beneficiary duty is to the normal confidentiality rules. A remark in the Comments suggests that the normal confidentiality rules still apply (with the trustee as the "client") with the consequence that the lawyer will have very limited ability to make disclosures and in some jurisdictions will be perhaps entirely precluded from doing so. Thus, the duty apparently created by the rule erodes as the nuances are considered.

158. See Hoopes v. Carota, 543 N.E.2d 73 (N.Y. 1989) (applying Garner to beneficiary suit against trustee). A more categorical approach is applied to trustees under the Employee Retirement Income Security Act. See Becher v. Long Island Lighting Co., 129 F.3d 268, 272 (2d Cir. 1997) (stating that "an cmployer acting in the capacity of ERISA fiduciary is disabled from asserting the attorney-client privilege against plan beneficiaries on matters of plan administration"); but see United States v. Mett, 178 F.3d 1058 (9th Cir. 1999) (finding that privilege does apply where trustee consults counscl in anticipation of charges by beneficiarics).

159. Tuttlc, supra note 67 , at 924 . 
tax subsidies, the Internal Revenue Service and other taxing authorities. ${ }^{160}$ The resources of these agencies, however, seem scant relative to their responsibilities.

Given the relative weakness of monitoring, it is arguable that the professional responsibilities of lawyers are exceptionally important in this sphere. Moreover, the deficiencies of a norm, such as Model Rule 1.13, ${ }^{161}$ which precludes disclosure of wrongdoing outside the organization, are especially severe here. Beneficiaries of a charitable organization typically have little or no participatory or monitoring role in its governance. This situation occurs occasionally in the business sphere, but it is routine with charities. Thus, the monitoring role of government agencies is especially important, and so is the ability of the lawyers to go outside the organization to make disclosures to these agencies.

\section{Informal Associations}

In the past, legal doctrine has tended to draw a sharp distinction between formally and informally organized associations. While formally organized ones were treated as entities, informal organizations were treated as joint individual representations. ${ }^{162}$ Thus, the lawyer's duties may depend strongly on matters of documentary formality, for example, whether articles of incorporation have been filed. However, the argument of this Article suggests that whether the client should be treatcd as an entity should depend, less on matters of form, and more on whether the relations in question have sufficient structure to constitute a Framework of Dealing. ${ }^{163}$ Parties who have not organized formally may have developed an authority structure and a sense of common goals sufficient to permit a distinction between organizational and individual interests. In such situations, the lawyer should commit herself to this Framework of Dealing. Refusing to do so may impair the constituents' ability to act in a coordinated fashion.

Suppose, for example, that several individuals get together and hire a lawyer to litigate a series of claims with common issues. Perhaps they are a group of homeowners seeking to enjoin the activities of a nearby factory or to recover damages from it. Perhaps they have been injured in various ways by asbestos produced by the defendant. Assume they agree in writing that they will all accept any settlement approved by the majority, so long as it is not manifestly unfair to any of them.

160. See James J. Fishman \& Stephen Schwartz, Nonprofit Organizations: Cases and Materials, 213, 254-59, 351-55 (2d ed. 2000).

161. See supra Part 1V.A.

162. E.g., Hayes v. Eagle-Pitcher Indus., Inc., 513 F.2d 892 (10th Cir. 1975).

163. See Halverson v. Convenient Food Mart, 1nc., 458 F.2d 927, 930 (7th Cir. 1972). 
Such agreements are unenforceable if the representation is considered joint. ${ }^{164}$ Thus, a lawyer could not conclude an aggregate settlement if any member of the group reneged. A dissenter who took a position adverse to the others might also be able to disqualify the lawyer from continuing to represent the other group members. This conclusion would follow no matter how informed the initial agreement was and without regard to the fairness of the initial agreement or the aggregate settlement. This treatment provides strong protection to anyone who changes her mind. But it also may have real costs. Some or all of the members of the group may not be willing to join in the suit without some assurance that all will be effectively bound. The option of easy defection raises the expected costs of undertaking the project in the first place.

While conceding that courts would be likely to apply jointrepresentation norms, Geoffrey Hazard and William Hodes argue that it would be better to treat the litigants as an organization and to permit the lawyer to act under Model Rule 1.13, based on the instruction of the majority (the organization's "duly authorized" constituents). ${ }^{165}$ This is in the spirit of Brandeis's "counsel for the situation" view. A Framework of Dealing can be inferred from common understanding and express agreement without formal organization. There are risks to this kind of collective action, but they are not materially different from the risks routinely run by constituents of formally organized groups. There is no reason why the permissibility of such risks should turn on whether there has been formal organization.

\section{CONCLUSION}

How can we treat separate individuals with both common and conflicting interests as a unity-a single "client"-for the purposes of representation? The only plausible answer is that these individuals have adopted or developed, explicitly or implicitly, a structure that reconciles their differing interests and facilitates potential mutually beneficial collaboration. If this is the answer, then the lawyer's professional responsibilities should be defined in relation to this structure.

Conventional doctrine is excessively preoccupied with formality. It tends to assume that such a structure exists just because legal formalities of organization have been satisfied, and it often ignores that such structures are present in relations without formal organization. It draws elaborate and

164. See MODEL Rules, supra note 1, at R 1.8 (providing that a "lawyer who represents two or more clients shall not participate in making an aggregate settlement of the claims . . unless each client gives informed consent" after disclosure of settlement terms). For debate in the context of mass tort litigation, compare Nancy J. Moore, The Case Against Changing the Aggregate Settlement Rule in Mass Tort Lawsuits, 41 S. TEx. L. Rev. 149 (1999), with Lynn A. Baker \& Charles Silver, The Aggregate Settlement Rule and Ideals of Client Service, 41 S. TEx. L. REv. 227 (1999).

165. HAZARD, supra notc 67, at ill. 17-1; see also id. at ill. 17-4. 
often implausible inferences from the fact of formal organization. At the same time, it disparages efforts such as Brandeis's in the Lennox case to represent a "situation," even when such informal collaboration has a discernible normative structure with clear implications for the resolution of conflict.

Once conventional doctrine identifies a client as an "entity," it tends to either ignore its normative structure for purposes of ethical decision making or to focus on only part of it. The Control Group approach ignores the structure; the Authority Structure looks at just part of it.

This Article has argued that the focus of ethical analysis should be, not on formality, but on the normative structure of the collaborative relationships. When there is no such structure, or where the structure is not sufficiently determinate to resolve the conflicts the lawyer faces, she should adopt the principles that conventional doctrine has developed for joint representation. When there is a sufficiently rich structure-a Framework of Dealing - she should define her professional responsibilities in terms of this structure. She should look first to its authority norms, and in many situations, she will not need to look farther. But authority norms will not resolve all cases. Substantive fiduciary norms form an important part of the Framework of Dealing. Where authority norms are indeterminate, or where they are in conflict with fiduciary norms, the lawyer needs to look also to the substantive norms in defining her obligations. 
